\title{
The impact of natural versus anthropogenic aerosols on atmospheric circulation in the Community Atmosphere Model
}

\author{
Robert J. Allen $\cdot$ Steven C. Sherwood
}

Received: 14 October 2009/Accepted: 17 August 2010/Published online: 31 August 2010

(C) The Author(s) 2010. This article is published with open access at Springerlink.com

\begin{abstract}
The equilibrium response of atmospheric circulation to the direct radiative effects of natural or anthropogenic aerosols is investigated using the Community Atmosphere Model (CAM3) coupled to two different ocean boundary conditions: prescribed climatological sea surface temperatures (SSTs) and a slab ocean model. Anthropogenic and natural aerosols significantly affect the circulation but in nearly opposite ways, because anthropogenic aerosols tend to have a net local warming effect and natural aerosols a net cooling. Aerosol forcings shift the Intertropical Convergence Zone and alter the strength of the Hadley circulation as found in previous studies, but also affect the Hadley cell width. These effects are due to meridional gradients in warming caused by heterogeneous net heating, and are stronger with interactive SST. Aerosols also drive model responses at high latitudes, including polar near-surface warming by anthropogenic aerosols in summer and an Arctic Oscillation (AO)-type responses in winter: anthropogenic aerosols strengthen wintertime zonal wind near $60^{\circ} \mathrm{N}$, weaken it near $30^{\circ} \mathrm{N}$, warm the troposphere, cool the stratosphere, and reduce Arctic surface pressure, while natural aerosols produce nearly opposite changes. These responses are shown to be due to modulation of stratospheric wave-driving consistent with meridional forcing gradients in midlatitudes. They are more pronounced when SST is fixed, apparently because the contrast in land-ocean heating drives a predominantly
\end{abstract}

\section{R. J. Allen ( $\square)$}

Department of Earth System Science,

University of California Irvine, Irvine, CA 92697, USA

e-mail: rjallen@uci.edu

S. C. Sherwood

Climate Change Research Centre,

University of New South Wales, Sydney, Australia wavenumber-2 response in the northern hemisphere which is more efficient in reaching the stratosphere, showing that zonal heating variations also affect this particular response. The results suggest that recent shifts from reflecting to absorbing aerosol types probably contributed to the observed decadal variations in tropical width and AO, although studies with more realistic temporal variations in forcing would be needed to quantify this contribution.

Keywords Arctic Oscillation - Aerosol - Hadley cell · Atmospheric circulation

\section{Introduction}

Aerosols are important to the climate system because they affect the radiative balance of the planet. First, they scatter and absorb solar radiation, and therefore contribute to atmospheric solar heating and surface cooling (Ramanathan et al. 2001a). This is referred to as the aerosol direct effect. Because absorbing aerosols heat the atmosphere, they can also decrease relative humidity and evaporate clouds (Ackerman et al. 2000). This is referred to as the semi-direct effect and can cause additional heating of the surface. Aerosols also have an impact on cloud microphysical properties (and hence, the radiative properties). Because aerosols act as cloud condensation nuclei (CCN), an increase in aerosols leads to an increase in $\mathrm{CCN}$, which in turn leads to an increase in cloud droplet number density, a reduction in cloud droplet effective radius and ultimately, brighter clouds (Twomey 1977). This is referred to as the first aerosol indirect effect, which enhances reflection of solar radiation back to space by clouds (and also reduces the solar radiation reaching the ground). The smaller cloud droplets also promote suppression of 
precipitation. This is referred to as the second indirect effect and leads to an increase in cloud lifetime (Albrecht 1989).

Several studies have documented the climatic impacts of reflecting [e.g. sulfate and organic carbon (OC)] aerosols. For example, Roeckner et al. (1999) use a coupled general circulation model (GCM) with a tropospheric sulfur cycle and find that increasing anthropogenic sulfate aerosols mitigate greenhouse warming by reflecting shortwave radiation. They also find the intensity of the global hydrological cycle becomes weaker if direct and indirect sulfate aerosol effects are included. Moreover, the simulated temperature trends during the last half of the twentieth century are in better agreement with observations if both greenhouse gases and sulfate aerosols are included (e.g. Mitchell et al. 1995).

Sulfate aerosols can affect the large-scale atmospheric circulation, particularly in the tropics, causing a southward shift of the intertropical Convergence Zone (ITCZ) (Williams et al. 2001). This shift is attributed to a reduced interhemispheric temperature gradient since reflecting aerosols predominately cool the NH. Rotstayn and Lohmann (2002) suggests that this shift may have contributed to the Sahelian drought of the 1970s and 1980s. Similarly, Cox et al. (2008) finds that sulfate aerosols alter the meridional sea surface temperatures (SST) gradient in the equatorial Atlantic, which affects Amazonian precipitation; future aerosol reductions imply increasing risk of Amazonian drought.

Reflecting aerosols are also capable of affecting highlatitude circulation. Several studies (e.g. Robock 2000; e.g. Shindell et al. 2004) have shown that tropical volcanic aerosols (which are primarily composed of sulfate) affect NH high-latitude winter climate, causing a positive Arctic Oscillation (AO) anomaly. The conventional mechanism explaining this effect is heating of the low latitude stratosphere (and ozone loss at high latitudes, which cools the polar lower stratosphere) enhances the meridional temperature gradient and strengthens the westerly winds near the tropopause. The enhanced westerlies then propagate down to the surface via wave-mean flow interactions, creating a surface temperature response pattern typical of the AO. Stenchikov et al. (2002) also finds a positive AO response results from low latitude cooling of the troposphere (since volcanic aerosols predominantly reflect solar radiation).

Recent research has focused on the impact of absorbing aerosols on regional climate, especially in the South Asian region, where emissions of fossil fuel black carbon (BC) increased by $\sim 6$-fold since 1930 (Ramanathan et al. 2005). Based on equilibrium model experiments with prescribed SSTs (as well as prescribed aerosol forcing), Chung et al. (2002) and Menon et al. (2002) show that absorbing aerosols lead to enhanced low-level convergence and precipitation over the haze area, including India and China. Bollasina et al. (2008) reach a similar conclusion, finding that in years when more aerosols are observed in May, cloud and precipitation amounts are reduced, increasing the surface temperature through solar heating. This results in a stronger June/July monsoon. Similarly, Randles and Ramaswamy (2008) find that at higher extinction-optical-depths, enhanced low-level convergence and ascent overcome the stabilizing effects of absorbing aerosols and strengthens the monsoon. However, prescribed increases in scattering aerosols alone has the opposite effect. A weakening of the monsoon is obtained either with prescribed SSTs (Chung and Ramanathan 2006; Ramanathan et al. 2007) or when prognostic SSTs in a coupled model can respond to the aerosol forcing (Ramanathan et al. 2005; Meehl et al. 2008). This weakening is caused by reduced evaporation over the Indian Ocean, a reduced land-sea temperature contrast and meridional SST gradient in the northern Indian Ocean, and increased atmospheric stability.

A few studies have identified broader impacts of absorbing aerosol forcing. Wang (2004) uses an interactive aerosol-climate model based on equilibrium simulations with CCM3 and a slab ocean model to examine the direct radiative forcing of $\mathrm{BC}$ aerosols. He finds that $\mathrm{BC}$ causes a significant change in tropical convective precipitation, with a strengthened (weakened) Hadley cell in the Northern (Southern) Hemisphere. These results are similar to Roberts and Jones (2004) and Yoshimori and Broccoli (2008). Wang (2004), however, concludes that the effects of BC aerosols on climate are more significant at the regional, rather than the global, scale. Because he assumes BC is externally mixed (physically separate from other particles) the aerosol effects on climate are likely underestimated (Ramanathan and Carmichael 2008).

To address the uncertainty in the mixing state of $\mathrm{BC}$, Chung and Seinfeld (2005) conduct separate GCM experiments assuming $\mathrm{BC}$ is both externally and internally mixed. They find significantly more warming with internally mixed $\mathrm{BC}, 0.54$ versus $0.29 \mathrm{~K}$ for the $\mathrm{NH}$ annual mean surface air temperature. Similarly, internally mixed $\mathrm{BC}$ yields enhanced atmospheric circulation changes, with a larger northward shift of the ITCZ, and larger increases (decreases) in precipitation between 0 and $20^{\circ} \mathrm{N}\left(0-20^{\circ} \mathrm{S}\right)$.

Relatively little attention has been devoted to globalscale/remote responses to absorbing aerosols. Kim et al. (2006) find that absorbing aerosols (dust and black carbon) excite a planetary-scale teleconnection pattern in sea level pressure, temperature, and geopotential height spanning north Africa through Eurasia to the north Pacific. They also show that the surface temperature signature associated with the aerosol-induced teleconnection is very similar to the 
spatial pattern of observed long-term trend in surface temperature over Eurasia. Similarly, Chung and Ramanathan (2003) investigate the influence of the interannual variability of the SE Asian haze on global climate. Two CCM3 experiments are conducted, representing extreme locations of the forcing. The remote impacts of the two experiments are significantly different, with the extended haze experiment yielding zonal wind changes similar to those associated with the positive AO (the shrunk haze experiment yields negligible changes). The SE Asian haze may therefore partially explain the the observed increase in AO variability (Feldstein 2002). In addition to interannual variability, aerosols have also exhibited relatively large trends over the latter half of the twentieth century, with increasing global emissions of BC (although they have fallen somewhat since 1990) (Novakov et al. 2003; Ito and Penner 2005; Bond et al. 2007) and decreasing emissions of sulfate aerosols since the 1970s (van Aardenne et al. 2001; Smith et al. 2004). A recent study attributes up to 75\% of the Arctic surface temperature increase since 1976 to aerosols, specifically the decrease in sulfate in North America and Europe and increase in BC from SE Asia (Shindell and Faluvegi 2009). Relatively little is known about how such aerosol trends have affected atmospheric circulation.

The above studies compose a complicated and uncertain overall picture of the regional and global climate impacts of aerosols, based on a variety of aerosol representations and boundary conditions. Some uncertainty stems from a lack of knowledge about the spatial and temporal evolution of aerosol emissions, especially BC and organic carbon (Bond et al. 2007). Additional uncertainty comes from issues in how to model the aerosol effect. In most GCMs, the absorbing aerosol forcing (primarily BC) is underestimated by a factor of 2-4 (Sato et al. 2003; Koch et al. 2009). This underestimation is due to a number of factors, including neglect of the internally mixed state of $\mathrm{BC}$ with other aerosols, neglect of biomass burning (about $40 \%$ of total $\mathrm{BC}$ emission) and $\mathrm{BC}$ concentrations that peak too close to the surface (Ramanathan and Carmichael 2008). There is also uncertainty in the the relative amounts of different aerosol types. Finally, studies make different assumptions as to the behavior of SST, which is clearly important in that cooling the surface (at least in the Tropics) is a key avenue by which aerosols can alter the circulation.

In this study, we simulate the direct effect of aerosols using the Community Atmosphere Model version 3 (CAM3, Collins et al. 2004). We bring some clarity to the role of direct aerosol forcing in driving circulation changes by using recent observationally derived forcing estimates, which are significantly higher than those used in most previous model studies; by examining the sensitivity to ocean behavior and aerosol properties, which can significantly affect atmospheric responses; and by analyzing aspects of the global circulation response that have not been widely examined. For simplicity, we examine only equilibrium responses, and ignore microphysical (indirect) effects on clouds. The paper is organized as follows: Sect. 2 discusses the aerosol forcing estimate used in this analysis and the experiment design for the global modeling. Section 3 presents the results, including circulation changes at low latitudes (e.g. mean meridional mass circulation changes) and mid/high-latitudes (zonal wind changes and the AO). Conclusions follow in Sect. 4. A companion paper (Allen and Sherwood 2010) focused on the effect of aerosol heating on cloud distributions and consequent "semi-direct" effects on global climate.

\section{Experimental design}

\subsection{Satellite derived aerosol forcing}

We use the satellite-based aerosol forcing of Chung et al. (2005) (hereafter, CH05), which is based on the Moderate Resolution Imaging Spectroradiometer (MODIS), with gaps and errors filled and corrected using the Georgia Tech/ Goddard Global Ozone Chemistry Aerosol Radiation and Transport (GOCART) model, as well as ground based observations from the AErosol RObotic NETwork (AERONET). The anthropogenic fraction of the aerosol forcing is obtained by differencing the natural and total aerosol forcing. The natural forcing is obtained from two independent sources. The standard estimate (and the one we use) is simply the prediction of the GOCART model (Chin et al. 2002). The second approach-which provides a lower bound on the natural fraction-uses the ratio of MODIS aerosol optical depth (AOD) from larger aerosol particles to that of all particles (since anthropogenic aerosols are mostly sub-micron sized). The single scattering albedo (SSA) and asymmetry parameter are also derived from GOCART and adjusted based on AERONET observations. These parameters are then introduced into the Monte-Carlo Aerosol Cloud Radiation (MACR) model (Podgorny et al. 2000) with ISCCP (International Cloud Climatology Project) D2 cloud data to derive, for the years 2000-2003, the aerosolinduced reduction of solar radiation at the surface $\left(F_{\mathrm{SFC}}\right)$ and increase in atmospheric solar absorption $\left(F_{\mathrm{ATM}}\right)$. We note that the aerosol forcing was likely different (i.e., larger SSA due to a larger ratio of sulfate to carbon) in earlier times (Smith et al. 2004; Bond et al. 2007).

The global, annual mean anthropogenic aerosol forcing thus obtained is $3.1 \mathrm{~W} \mathrm{~m}^{-2}$ in the atmosphere (SSA ranges from 0.85 to 0.88 ) and $-3.5 \mathrm{~W} \mathrm{~m}^{-2}$ at the surface. Based on sensitivity experiments $\mathrm{CH} 05$ estimated the corresponding uncertainties at 20 and $10 \%$, respectively. For a given 
aerosol type, the major sources of uncertainty are the SSA and the vertical distribution of the aerosols. For example, if all aerosols are confined below $1 \mathrm{~km}(2-4 \mathrm{~km})$, atmospheric absorption decreases (increases) to $2.7(3.2) \mathrm{W}$ $\mathrm{m}^{-2}$. There is also uncertainty in distinguishing natural from anthropogenic aerosols. If the MODIS fine mode fraction (ratio of small mode to total optical depth) is used for the anthropogenic fraction over the ocean (instead of GOCART estimates), atmospheric forcing decreases to $3.0 \mathrm{~W} \mathrm{~m}^{-2}$. There may also be a bias, however, in MODIS retrievals of this ratio, which have been found to be systematically larger than in situ measurements by 0.2 in the Aerosol Characterization Experiment (ACE)-Asia region (Anderson et al. 2005). This underestimation of retrieved particle size distributions is consistent with an analysis of the Puerto Rico Dust Experiment (PRIDE) data set (Levy et al. 2003). These results suggest a possible overestimation of satellite-derived anthropogenic aerosol forcing.

The forcing estimates used here are similar to others recently developed from satellite and other observations. In terms of the top of the atmosphere (TOA) direct radiative forcing under cloudy skies, Yu et al. (2006) obtains $-0.5 \pm 0.33 \mathrm{~W} \mathrm{~m}^{-2}$, compared to CH05's $-0.35 \pm 0.25$. In terms of all-sky conditions (i.e., no clouds) Bellouin et al. (2005) obtains $-0.8 \pm 0.2 \mathrm{~W} \mathrm{~m}^{-2}$ compared to CH05's $-1.08 \mathrm{~W} \mathrm{~m}^{-2}$. For atmospheric forcing under clear skies, Bellouin et al. (2005) obtains $2.5 \mathrm{~W} \mathrm{~m}^{-2}$ (all aerosols), compared to CH05's estimate of $3.4 \mathrm{~W} \mathrm{~m}^{-2}$ (anthropogenic aerosol only). Thus, aerosol forcings now seem to be known to an accuracy of $50 \%$ or better globally. Importantly, these estimates are several times larger than those derived previously from models, which average $1.24 \mathrm{~W}$ $\mathrm{m}^{-2}$ for clear-sky conditions (Forster et al. 2007), indicating that many published model results may significantly underestimate some aspects of aerosol-forced responses.

\subsection{Model experiment details}

It is not practical to run idealized/equilibrium aerosol forcing simulations with full ocean models due to the great expense of reaching equilibrium in the ocean with each aerosol scenario. The remaining options are to prescribe SSTs (thus preventing any ocean-modulated response), or use a slab ocean model (which often exaggerates local responses to surface flux anomalies because ocean heat transports cannot change). To assess the robustness of our results to ocean behavior, we repeat otherwise identical experiments with both of these: a "data ocean model" (DOM) (i.e., fixed climatological seasonal cycle of SSTs) and a slab ocean-thermodynamic sea ice model (SOM). To our knowledge this has been done before only by Wang (2004), who did not show any of the DOM results. With the $\mathrm{SOM}$, the ocean mixed layer contains an internal heat source (Q flux) representing seasonal deep water exchange and horizontal ocean heat transport. SOM (DOM) experiments are run for 150 (100) years, the last 100 (70) of which are used in this analysis, during which there was no significant trend in TOA net energy flux. The DOM and SOM setups constitute oceans with infinite and (at equilibrium) zero local heat capacity, respectively, which we argue is likely to bracket the behavior that would occur with a more realistic ocean. While anomalous ocean heat transports could cause SSTs in some regions to change less or even in the opposite direction to what a slab model would predict, the predominant response is likely to be at least qualitatively captured in most places, as suggested for example by modeled responses to aerosol forcing (Evan et al. 2009). The DOM simulation, on the other hand, may be representative of the response to forcing variations on intraseasonal and shorter time scales where the ocean response would be muted by thermal inertia.

Monthly aerosol forcings $\left(F_{\mathrm{ATM}}\right.$ and $\left.F_{\mathrm{SFC}}\right)$-as estimated by $\mathrm{CH} 05$ - are incorporated into the $\mathrm{CAM}$ radiation module. Aerosol absorption is uniformly distributed throughout the lowest $\sim 3 \mathrm{~km}$ of the atmosphere, in accord with observation (Ramanathan et al. 2001b). Although aerosol forcing is almost independent of zenith angle $(\theta)$ when $\theta$ is small, aerosol forcing $\rightarrow 0$ as $\theta \rightarrow 90^{\circ}$. Thus, the added aerosol forcing is multiplied by a scaling factor that depends on $\theta$ (Chung 2006). Although prescribed aerosol forcing is not allowed to change in response to meteorological (e.g., wind, precipitation) changes, Chung (2006) shows that this approach yields similar results (i.e., changes in precipitation) as the on-line approach, where the distribution and amount of aerosols in the atmosphere are predicted based on emissions (e.g., Wang 2007). CAM is run at T42 resolution $\left(\sim 2.8^{\circ} \times 2.8^{\circ}\right)$ with 26 vertical levels.

Table 1 lists the CAM experiments performed, as well as the five signals (i.e., differences between experiments) that will be discussed. The anthropogenic + natural

Table 1 Definition of the three CAM aerosol experiments and signals (differences between experiments)

\begin{tabular}{ll}
\hline Experiment & Aerosols used \\
\hline NULL & None \\
NATURAL & Natural \\
ALL & Anthropogenic + natural \\
\hline Signal & Experiments used \\
\hline NAT & NATURAL-NULL \\
ALL & ALL-NULL \\
ANTHRO & ALL-NATURAL
\end{tabular}

Each experiment was run with a DOM (fixed SST) and SOM (slab ocean) 
experiment is compared to two control runs, the natural experiment (to get the anthropogenic signal, designated as ANTHRO) and a control run with no aerosols (to get the total aerosol signal, designated as ALL). The natural aerosol signal (designated as NAT) is obtained by comparing the natural experiment with the no aerosol control run. CAM default aerosol are removed by setting the aerosol mass mixing ratio for the five aerosol species (carbonaceous, dust, sea salt, sulfur, and volcanic) to zero.

To help interpret the results (in particular the importance of the aerosol spatial heterogeneity), two additional CAM SOM experiment are performed. Both use default CAM settings (e.g. aerosols), except a globally uniform heating source of $0.1 \mathrm{~K} \mathrm{day}^{-1}$ (about $3.5 \mathrm{~W} \mathrm{~m}^{-2}$, similar to $F_{\text {ATM }}$ ) is added to the lowest $\sim 3 \mathrm{~km}$ of the atmosphere (as with ANTHRO) in the experiment; the control is analogous, but has no heating source. The difference between these two experiments (i.e. the signal) is designated as UHT (uniform heating). Results are based on the last 30 years of a 70 year integration.

Figure 1 shows the prescribed zonal mean DJF and JJA atmospheric heating $\left(F_{\mathrm{ATM}}\right)$ and reduction in surface solar radiation $\left(F_{\mathrm{SFC}}\right)$ for the three experiments. The forcing is largest in the $\mathrm{NH}$, where the major sources of aerosols exist. There is also a clear seasonal signal, with larger forcing during each hemisphere's summer, when solar radiation is maximum. ANTHRO $F_{\mathrm{ATM}}$ is much larger than that for NAT, due to a greater proportion of absorbing aerosols. Based on anthropogenic aerosols only, the SSA is 0.85-0.88; adding natural aerosols significantly decreases the absorption, increasing the total SSA to 0.93-0.95 (Chung et al. 2005).

During DJF, the maximum forcing occurs near $10^{\circ} \mathrm{N}$, primarily due to anthropogenic aerosols from central Africa (due to biomass burning) and India (due to fossilfuel burning) and natural aerosols (dust) from central Africa. ANTHRO $F_{\mathrm{ATM}}\left(F_{\mathrm{SFC}}\right)$ peaks near $6(-7) \mathrm{W} \mathrm{m}^{-2}$. The NAT forcing is substantially less, with $F_{\mathrm{ATM}}\left(F_{\mathrm{SFC}}\right)$ peaking near $0.5(-3) \mathrm{W} \mathrm{m}^{-2}$. Because ANTHRO $F_{\text {ATM }}$ is nearly equal in magnitude to $F_{\mathrm{SFC}}$, ANTHRO is comprised of a high proportion of absorbing aerosols. However, because NAT $F_{\mathrm{ATM}}$ is only $\sim 20 \%$ of $F_{\mathrm{SFC}}$, a low proportion of absorbing aerosols (i.e., a high proportion of reflecting aerosols) comprise NAT.

During JJA, ANTHRO $F_{\text {ATM }}$ for the entire NH is at least $3 \mathrm{~W} \mathrm{~m}^{-2}$. Two distinct maxima exist at $5^{\circ} \mathrm{S}$ and $40^{\circ} \mathrm{N}$, with $F_{\text {ATM }}$ approaching 7 and $8.5 \mathrm{~W} \mathrm{~m}^{-2}$, respectively. These maxima are due to aerosols from southern Africa and southeast Asia/China. NAT has substantially less heating, with most of the NH $F_{\text {ATM }}$ between 0.5 and $1.0 \mathrm{~W} \mathrm{~m}^{-2}$, peaking near $15^{\circ} \mathrm{N}$ at $1.2 \mathrm{~W} \mathrm{~m}^{-2}$. India, the Middle East, the Gobi Desert, and parts of China contribute most to NAT, again primarily due to dust. In terms of $F_{\mathrm{SFC}}$, the disparity between anthropogenic and natural aerosol is much less. ANTHRO (NAT) minimizes at $\sim-9(-5) \mathrm{W}$ $\mathrm{m}^{-2}$ near $40(15)^{\circ} \mathrm{N}$. Similar to DJF, ANTHRO (NAT) JJA
Fig. 1 DJF (top) and JJA (bottom) zonal mean reduction in surface solar radiation $\left(F_{\mathrm{SFC}}\right.$; left) and atmospheric heating $\left(F_{\mathrm{ATM}} ;\right.$ right $)$ for each experiment. Units are $\mathrm{W} \mathrm{m}^{-2}$
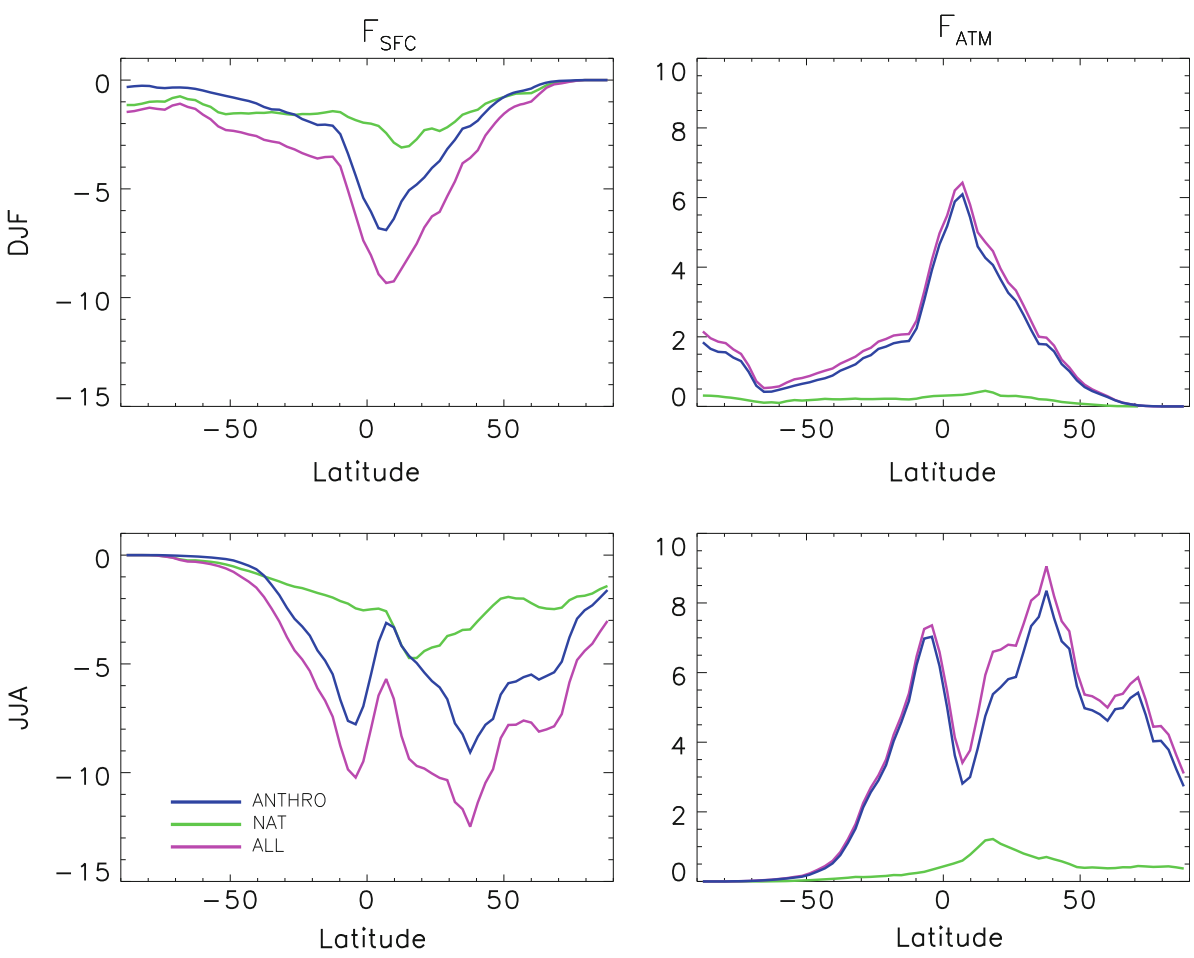
possess a much higher (lower) proportion of absorbing versus reflecting aerosols. This is true year-round.

Note that the atmospheric absorption by anthropogenic aerosols approximately balances the surface cooling-that is, the net effect is to move energy from the ocean to the atmospheric boundary layer with little net power input. This will heat the system overall when SSTs are fixed, but with a slab ocean, net fluxes into the surface cannot change over time so the net system heating will be small. By contrast, natural aerosols cool the surface without heating the atmosphere much. This will produce a net power sink over land areas and oceans represented by a slab model, but will have no effect over the DOM ocean. Thus the overall power input by aerosols and its land-ocean contrast will depend on both the aerosol type and the assumed ocean behavior.

\section{Results}

\subsection{Vertical temperature structure}

Figure 2 shows the vertical cross section of temperature change $(\Delta T)$ in DJF and JJA, for both ocean conditions and aerosol types. In most of the experiments the troposphere warms, although natural aerosols (NAT) produce little warming with fixed SST (DOM) and significant cooling with the slab ocean (SOM). This accords with the differences in net forcing between SOM and DOM, with the surface energy sink well exceeding the atmospheric source in the DOM case, cooling the oceans and thus the troposphere. Low latitudes tend to warm the most in DJF, broadly consistent with the location of maximum aerosol heating at that time (Fig. 1), although ANTHRO warming peaks over Antarctica and near $40^{\circ} \mathrm{N} / \mathrm{S}$. Because the peak heating is near $10 \mathrm{~N}$, the midlatitude peaks must be driven by changes in the circulation (see Sect. 3.3). The Antarctic warming is probably driven by local forcing due to strong summertime insolation. In JJA the tropospheric changes are strongest in the northern hemisphere where the forcing is largest; in particular there is strong warming in JJA in the Arctic lower troposphere.

In the NAT experiments, the stratosphere generally warms despite the lack of any direct forcing there. The reason for this is unclear. No similarly broad change occurs with ANTHRO forcing, but strong localized changes occur in the polar regions where the stratospheres tend to cool with ANTHRO forcing but warm with NAT. These changes are stronger in the Arctic than the Antarctic, and stronger in local winter than in summer. Since there is no direct forcing in the stratosphere, these changes must be associated with stratospheric dynamical responses (Sect. 3.3).
It is interesting to compare more carefully the slab ocean and fixed SST experiments. They produce similar $\Delta T$ in most places despite the different ocean response to surface forcing. But a significant exception is that the wintertime polar stratospheric (and to a lesser extent tropospheric) changes noted above are much stronger in the DOM (fixed $\mathrm{SST}$ ) runs than in the SOM runs. This difference is much larger in the Arctic winter than the Antarctic one, and is greater for ANTHRO forcing than for NAT. The larger difference in DOM suggests that land-ocean contrasts may play a role in driving the dynamical responses (Sect. 4). Another somewhat surprising result is that, with ANTHRO forcing in DJF, the tropical troposphere warms at least as much in SOM as in DOM; in the other three cases, DOM warms more, as would be expected from the lack of ocean cooling. Moreover, even in JJA the slab ocean has significantly less impact on tropical warming for ANTHRO than for NAT, despite the surface heat sink being similar for both aerosol forcings. The reasons for this are not clear but may again have to do with differing dynamical responses with the two oceans, as shown by evidence noted above.

The large Arctic near-surface warming is interesting in light of its possible relevance to recent trends (c.f. Shindell and Faluvegi 2009). In these experiments it is enhanced by snow and ice melt (not shown) and moreover by decreased low cloud amounts over land areas (Allen and Sherwood 2010), both of which lead to increased solar heating. Despite an applied surface forcing of only $-2 \mathrm{~W} \mathrm{~m}^{-2}$ (Fig. 1) at high NH latitudes, the equilibrium change in net short wave radiation at the surface is nearly $10 \mathrm{~W} \mathrm{~m}^{-2}$ for both ANTHRO runs. It is interesting that this warming is not significantly reduced with a slab ocean, which is probably because of the large fraction of land at high northern latitudes plus the fact that ocean circulation changes cannot occur in either experiment.

Compared to other absorbing aerosol studies (Chung and Seinfeld 2005; Yoshimori and Broccoli 2008), the vertical structure of warming for ANTHRO SOM is similar, but does not extend as far vertically. Chung and Seinfeld (2005) find maximum BC-induced warming (internally mixed aerosols) near $400 \mathrm{hPa}$ at $30^{\circ} \mathrm{N}$, especially during JJA, of about $1.2 \mathrm{~K}$. The corresponding warming in our study is $\sim 0.4 \mathrm{~K}$. The lesser warming found here is likely because ANTHRO SOM is forced with not only absorbing (i.e., BC) aerosols, but other anthropogenic aerosols, like sulfate, that tend to cool the surface and atmosphere. The global $(\mathrm{NH})$ annual mean $\Delta T_{\text {sfc }}$ is $0.09(0.18) \mathrm{K}$, compared to Chung and Seinfeld's $\Delta T_{\mathrm{sfc}}$ of $0.37(0.54) \mathrm{K}$. However, global cooling in ANTHRO SOM $\Delta T_{\text {sfc }}$ is similar to that of Wang (2004), who assumes externally mixed $\mathrm{BC}$ aerosols, at $0.09 \mathrm{~K}$ for the global annual mean. 
Fig. 2 DJF (top four panels) and JJA (bottom four panels) temperature change. Symbols represent significance (assessed with a standard $t$ test using the pooled variance) at the $90 \%$ (diamond), 95\% (cross) and 99\% (dot) confidence level. Units are $\mathrm{K}$

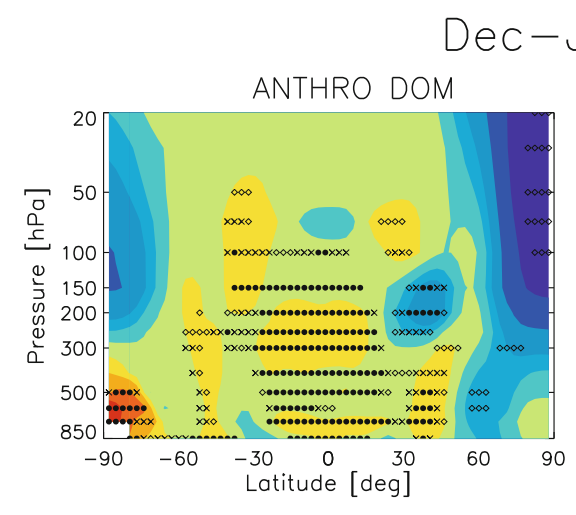

$$
\text { Jan-Feb }
$$
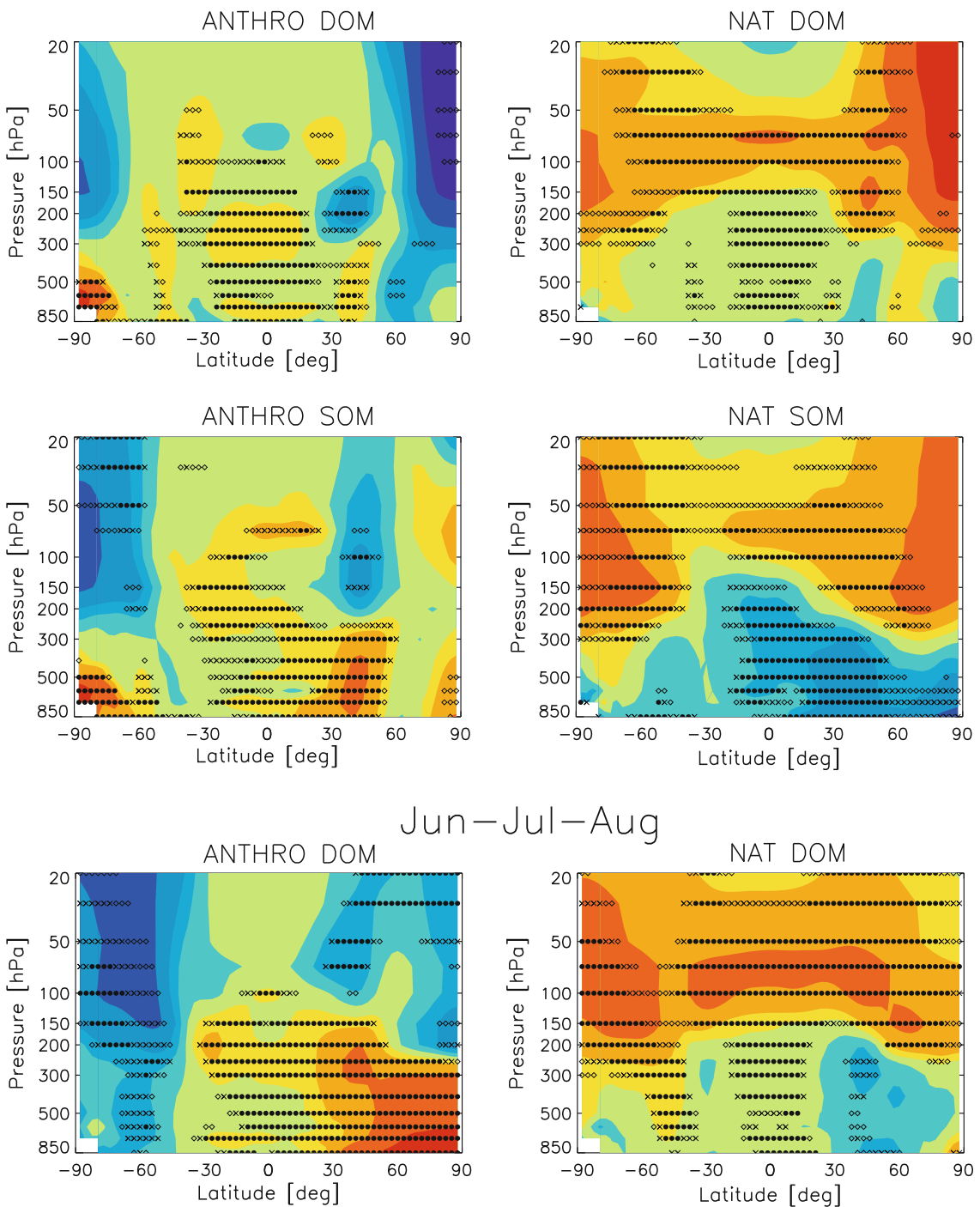

-Jul-Aug
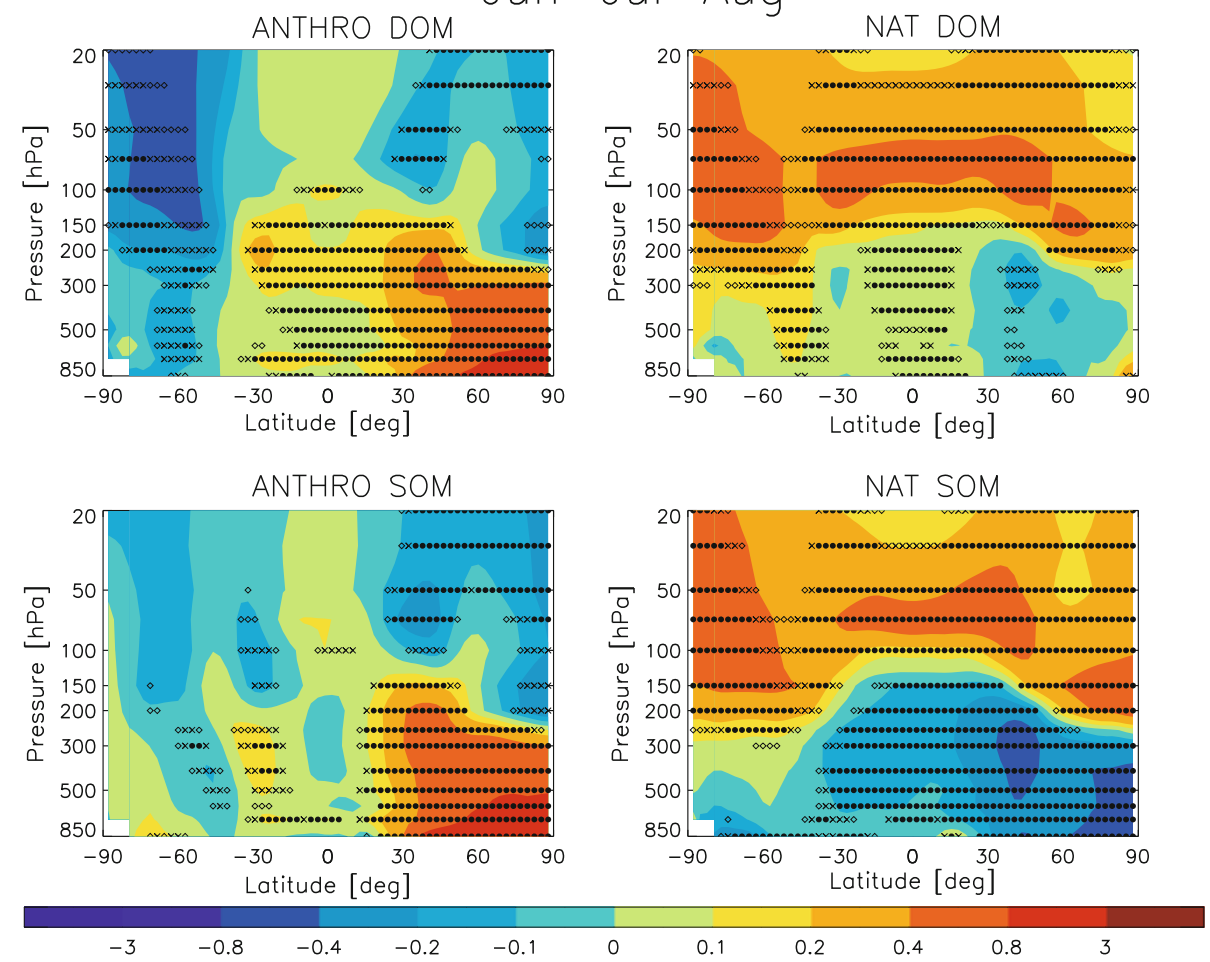

\subsection{Hadley cell/ITCZ}

Figure 3 shows the change in the mean meridional mass circulation $(\triangle \mathrm{MMC})$, defined by calculating the northward mass flux above a particular pressure level (i.e., a mass streamfunction). The clearest changes are to the Hadley cell, which is not surprising given that the forcings peak near the latitude of the ITCZ (Fig. 1). In both seasons and for both forcings, these are larger with the slab ocean. Furthermore, the changes are opposite for ANTHRO and NAT.

In DJF with a slab ocean, ANTHRO forcing weakens the MMC, while NAT strengthens it. The ANTHRO 
Fig. 3 DJF (top four panels) and JJA (bottom four panels) mean meridional mass circulation change (color shading). Negative (positive) values represent

counterclockwise (clockwise) circulation change. Symbols represent significance as in Fig. 2. Units are $10^{10} \mathrm{~kg} \mathrm{~s}^{-1}$. Also included is the climatological MMC (contour lines) based on the corresponding control experiment. Contour interval is $5 \times 10^{10} \mathrm{~kg} \mathrm{~s}^{-1}$, with negative values dashed
Dec-Jan-Feb
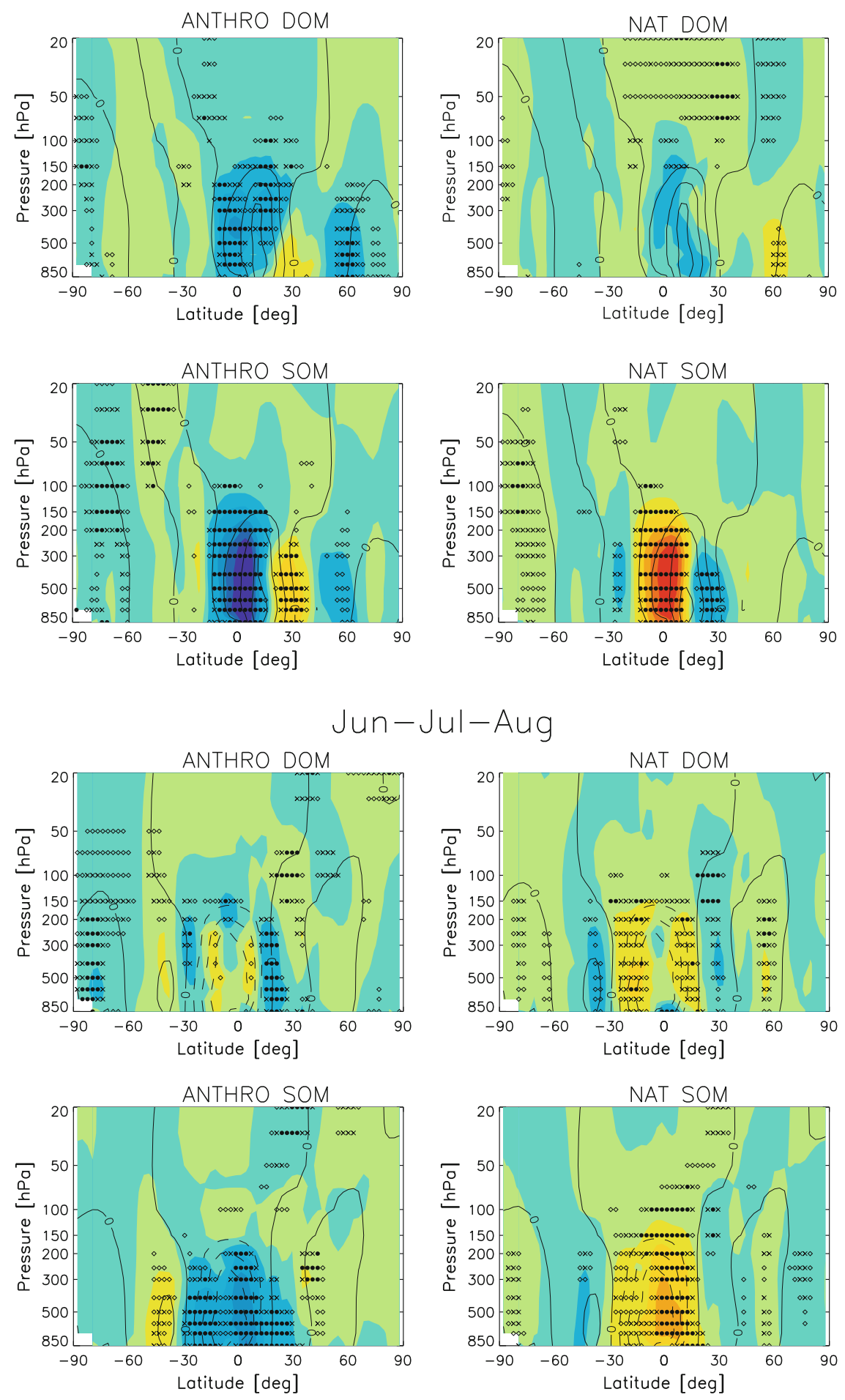

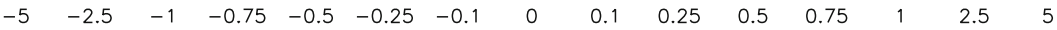

weakening also appears in DOM but not strongly. Opposite changes occur in JJA, with only the NAT signal appearing (weakly) in DOM. For ANTHRO forcing, this strengthening/weakening is associated with a northward shift of the tropical MMC maxima; NAT forcing shifts the MMC maxima southward. Table 2 shows that the MMC maxima shifts $\sim 0.5-1.0^{\circ}$ northward (southward) for ANTHRO (NAT) SOM. These results are consistent with other slab 
Table 2 Northward displacement of the tropical (top) MMC and (bottom) precipitation minus evaporation $(\mathrm{P}-\mathrm{E})$ maxima for both ocean boundary conditions

\begin{tabular}{|c|c|c|c|c|c|c|}
\hline & \multicolumn{3}{|l|}{ SOM } & \multicolumn{3}{|l|}{ DOM } \\
\hline & DJF & JJA & ANN & DJF & JJA & ANN \\
\hline \multicolumn{7}{|l|}{ MMC } \\
\hline ANTHRO & $0.61 * *$ & $0.99 * *$ & 0.18 & 0.06 & 0.03 & $-0.49 * *$ \\
\hline NAT & $-0.71 * *$ & -0.49 & -0.18 & 0.0 & 0.23 & 0.40 \\
\hline UHT & 0.01 & $-1.2 *$ & -0.32 & $X$ & $X$ & $X$ \\
\hline \multicolumn{7}{|l|}{$P-E$} \\
\hline ANTHRO & $1.6^{* *}$ & 0.12 & $\mathbf{0 . 7 9} * *$ & 0.60 & -0.08 & 0.11 \\
\hline NAT & $-1.6^{* *}$ & $-0.16^{* *}$ & $-0.53 * *$ & -0.23 & 0.0 & -0.06 \\
\hline UHT & 1.4 & $-0.29 *$ & 0.35 & $X$ & $X$ & $X$ \\
\hline
\end{tabular}

Significance is denoted by bold $(\geq 90 \%) ; *(\geq 95 \%)$ and $* *(\geq 99 \%)$. Units are degrees latitude. MMC is evaluated at $500 \mathrm{hPa}$. Precipitation is the sum of both convective and large scale precipitation

ocean aerosol studies focusing on the direct effects of BC aerosols (Wang 2004; Roberts and Jones 2004; Chung and Seinfeld 2005; Wang 2007; Yoshimori and Broccoli 2008), and the direct (Yoshimori and Broccoli 2008) and indirect (Rotstayn et al. 2000; Williams et al. 2001) effects of sulfate aerosols.

The change in MMC is associated with the change in inter-hemispheric SST difference, such that anomalous heat is transported from the warmed to the cooled hemisphere (Zhang and Delworth 2005; Broccoli et al. 2006; Mantsis and Clement 2009). Because most of the aerosol forcing is north of the equator, the associated $\Delta T$ is larger there too. ANTHRO aerosols warm the $\mathrm{NH}$ troposphere (Fig. 2), thus weakening the inter-hemispheric temperature difference in DJF and strengthening it in JJA. The resulting annual mean $\Delta \mathrm{SST}$ is $0.22 \mathrm{~K}$ in the northern hemisphere and $0.02 \mathrm{~K}$ for the $\mathrm{SH}$, in the slab ocean simulations. Because NAT aerosols cool the NH troposphere (Fig. 2), their effects are generally opposite to those of ANTHRO. For NAT SOM, the $\mathrm{NH}$ annual mean $\triangle \mathrm{SST}$ is $-0.28 \mathrm{~K}$, compared to $-0.12 \mathrm{~K}$ in the $\mathrm{SH}$. This argument is also consistent with the response (not shown) of the uniform heating experiment (UHT), where the MMC weakens in both DJF and JJA. This is because the SST warming is greater in the winter hemisphere in both seasons, leading to a weaker inter-hemispheric SST gradient. This also leads to northward displacement of the tropical MMC maxima (Table 2) during DJF (like ANTHRO), but southward displacement during JJA (like NAT).

In our experiments, the strength of the inter-hemispheric SST and the cross-equatorial heat transport (calculated as the product of the meridional velocity and temperature, $V T$ ) are closely related. The correlation of the interhemispheric $\triangle \mathrm{SST}$ and zonal (equatorial) mean $\Delta V T$ (averaged from 850 to $150 \mathrm{hPa}$ ) over three seasons (JJA, DJF and ANN) and four signals (NAT and ANTHRO for DOM and SOM) is -0.93 . Similarly, the corresponding correlation between the zonal (equatorial) mean $\Delta V T$ and $\Delta \mathrm{MMC}$ (evaluated at $500 \mathrm{hPa}$ ) is 0.99 . Thus, an increase in interhemispheric SST decreases the northward heat transport by modifying the MMC. Similar results are obtained with different definitions of the MMC (e.g., using other pressures or tropical latitudes) or by looking at $\Delta T_{700}$ rather than $\Delta \mathrm{SST}$. The changes in interhemispheric $\Delta \mathrm{SST}$, cross-equatorial heat transport, and MMC change are all smaller in DOM than SOM simulations.

As would be expected, the above changes are associated with a shift in the Intertropical Convergence Zone (ITCZ), reflected in the vertical velocity, convective precipitation, and cloud fields. The ITCZ moves northward in ANTHRO and southward in NAT, regardless of season, consistent with the shift of the tropical MMC maxima. Figure 4 shows the change in precipitation minus evaporation $(\mathrm{P}-\mathrm{E})$ in the SOM runs for DJF and JJA. The tropical P - E maxima is displaced northward, relative to the control integration, for ANTHRO SOM and southward for NAT SOM. Table 2 shows the magnitude of the displacement is up to $\sim 1.6^{\circ}$
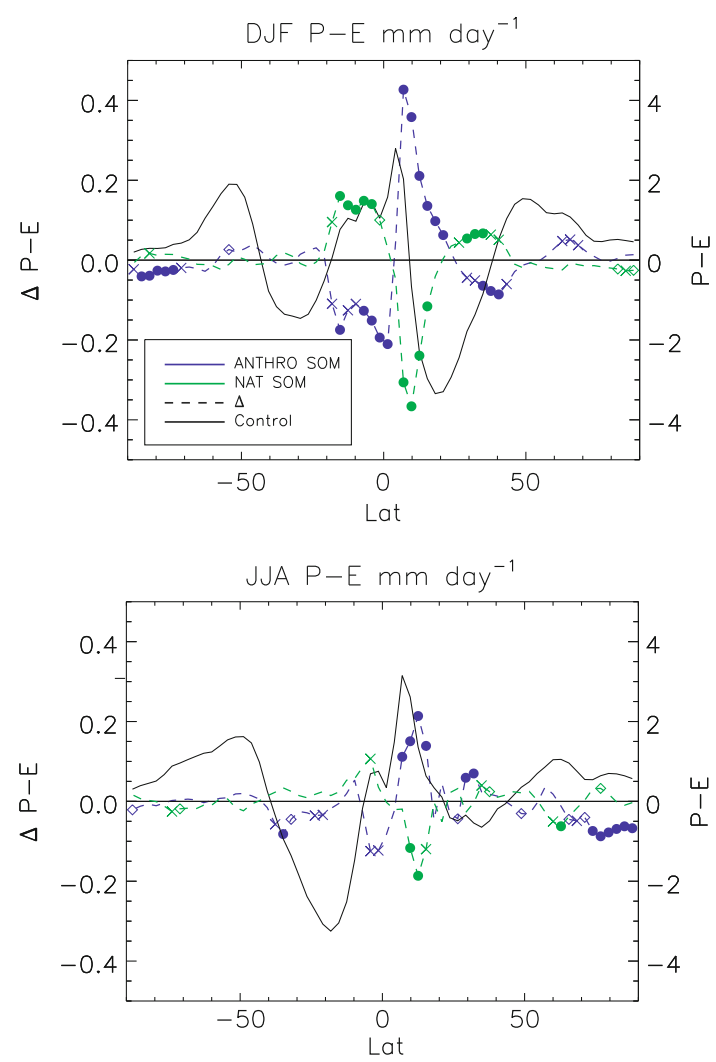

Fig. 4 Zonal DJF (top) and JJA (bottom) precipitation minus evaporation $(\mathrm{P}-\mathrm{E})$ change for ANTHRO and NAT SOM. Also included is $\mathrm{P}-\mathrm{E}$ from the control experiment. Symbols represent significance as in Fig. 2. Units are $\mathrm{mm}$ day $^{-1}$ 
during DJF for the SOM experiments, with generally smaller changes in the DOM runs. The UHT P - E signal is also consistent with its tropical MMC displacement, with a northward shift of the tropics during DJF and a southward shift during JJA.

\subsection{Zonal winds}

\subsubsection{Low-latitude response}

Figure 5 shows the change in zonal wind $(\Delta U)$ during the DJF and JJA seasons. As for the low-latitude MMC changes, the $\Delta U$ changes are generally opposite for the ANTHRO and NAT forcings. Unlike $\triangle M M C$, however, both surface boundary conditions (DOM and SOM) yield similar patterns and similar absolute magnitudes of zonal wind change.

The SOM-and to a lesser extent the DOM-experiments show a meridional displacement of the subtropical jets. Both the NH and SH jet tends to shift poleward from ANTHRO forcing, leading to expansion of the Hadley cell and the tropics; NAT forcing leads to equatorward jet displacement and contraction of the tropics. The meridional displacement of the jet $\left(\Delta \phi_{\text {jet }}\right)$ was quantified by interpolating the zonal wind to $0.5^{\circ}$ resolution using cubic splines and then locating the latitude of the maximum $\mathrm{NH}$ and SH zonal wind for each year-month in the upper troposphere $(250-150 \mathrm{hPa})$. Averaging over season and taking the difference of the mean jet location (experiment-control) yields the poleward jet displacement, as shown in Table 3. With both oceans, ANTHRO yields poleward displacement of the $\mathrm{NH}$ jet during every season except DJF, up to $0.42^{\circ}$ during boreal autumn (SON; not shown). Displacement is smaller and not significant in DJF as the decrease in wind occurs near the center of the jet, while the increase occurs nearly $20^{\circ}$ poleward of it. NAT-forced shifts of the $\mathrm{NH}$ jet are equatorward, and again largest for $\mathrm{SON}$ at $0.35^{\circ}$. Displacements of the $\mathrm{SH}$ jet are generally in the same direction (poleward for ANTHRO and equatorward for NAT), but smaller, in accord with the reduced aerosol forcing. The largest SH jet displacement occurs for ANTHRO DOM during SON and for ANTHRO SOM during JJA, where the SH jet moves poleward by $0.54^{\circ}$ and $0.27^{\circ}$, respectively. This suggests a maximum tropical widening of $\sim 0.5^{\circ}$ for ANTHRO SOM (during JJA) and $\sim 0.9^{\circ}$ for ANTHRO DOM (during SON); the corresponding maximum contraction (NAT JJA) is similar in magnitude at $\sim 0.4^{\circ}$. The seasons of maximum expansion-JJA and $\mathrm{SON}-$ correspond to the seasons with maximum aerosol absorption, at both low latitudes $\left(4.7\right.$ and $4.5 \mathrm{~W} \mathrm{~m}^{-2}$, respectively, for $\pm 30^{\circ}$ ), as well as globally. Similar results are obtained if other upper tropospheric/lower stratospheric pressure levels are used to measure the jet, or if $U$ is not interpolated before locating the jets.

Table 3 shows that alternative measures of tropical expansion/contraction are consistent with the subtropical jet displacements. These metrics include (1) the latitude of the subtropical MMC minima, defined as the $\mathrm{NH}$ and $\mathrm{SH}$ latitude where the MMC at $500 \mathrm{hPa}$ becomes zero poleward of the subtropical maxima; and (2) the latitude where precipitation minus evaporation $(\mathrm{P}-\mathrm{E})$ becomes zero on the poleward side of the subtropical minima (e.g. Hu and Fu 2007; e.g. Lu et al. 2007; e.g. Johanson and Fu 2009). Similar to the procedure used to find the jet displacement, zonal mean $\mathrm{MMC}$ and $\mathrm{P}-\mathrm{E}$ are first interpolated to $0.5^{\circ}$ resolution using cubic splines, and then the latitude of interest is located for each year-month for experiment and control. Although both metrics yield similar results, we emphasize the MMC statistic because aerosol semi-direct effects on clouds, and hence precipitation, likely make the $\mathrm{P}-\mathrm{E}$ metric noisier. During DJF, Table 3 shows that anthropogenic aerosols shift the tropics northward, by $\sim 0.4^{\circ}$ for the slab ocean, while natural aerosols shift the tropics southward by a similar amount. These results are consistent with the prior section (Table 2), with northward displacement of the ANTHRO MMC and P - E maxima (i.e. center of tropics) and southward displacement for NAT, due to different interhemispheric SST gradient changes. During JJA, however, both the MMC and P - E metrics yield tropical expansion for ANTHRO and contraction for NAT, of about $0.2^{\circ}$ for the slab ocean experiments. Similar tropical expansion for ANTHRO also occurs during SON. These other metrics are therefore consistent with the subtropical jet displacement, further supporting the notion that anthropogenic aerosols promote tropical expansion, especially during the seasons of larger aerosol forcing (JJA and SON).

One explanation used to account for tropical expansion/ contraction is that of Held (2000), where the Hadley cell latitude is proportional to the tropopause height and the gross dry static stability (potential temperature difference between the tropopause and surface, $\theta_{\mathrm{TP}}-\theta_{\mathrm{sfc}}$ ). Both Frierson et al. (2007) and Lu et al. (2007) show that a variety of global warming experiments yield increases in subtropical static stability, which reduces baroclinic growth rates and displaces the region of baroclinic instability onset poleward, resulting in tropical expansion. Similarly, Lorenz and DeWeaver (2007) show that tropical expansion is associated with raising of the tropopause, especially on the poleward flank of the jet. Lu et al. (2009) attributes the raising of the tropopause (and consequent tropical expansion) since 1958 to stratospheric cooling caused by greenhouse gas increases and stratospheric ozone depletion. This is consistent with Haigh et al. (2005), who found uniform (and high-latitude) heating of the lower 
Fig. 5 DJF (top four panels) and JJA (bottom four panels) zonal wind change (color shading). Symbols represent significance as in Fig. 2. Units are $\mathrm{m} \mathrm{s}^{-1}$. Also included is the climatological U (contour lines) based on the corresponding control experiment. Contour interval is $10 \mathrm{~m} \mathrm{~s}^{-1}$, with negative values dashed

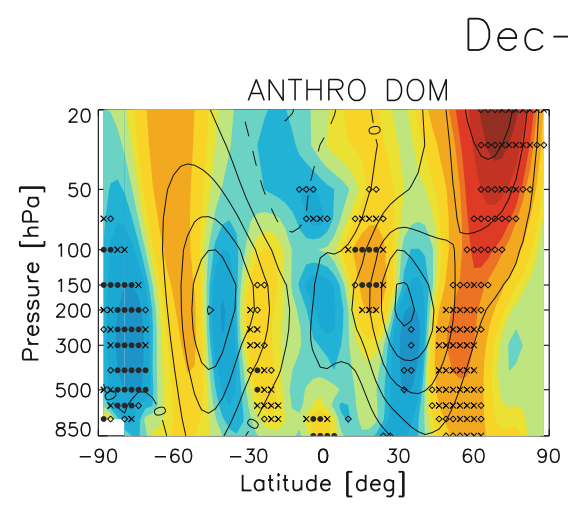

Jan-Feb
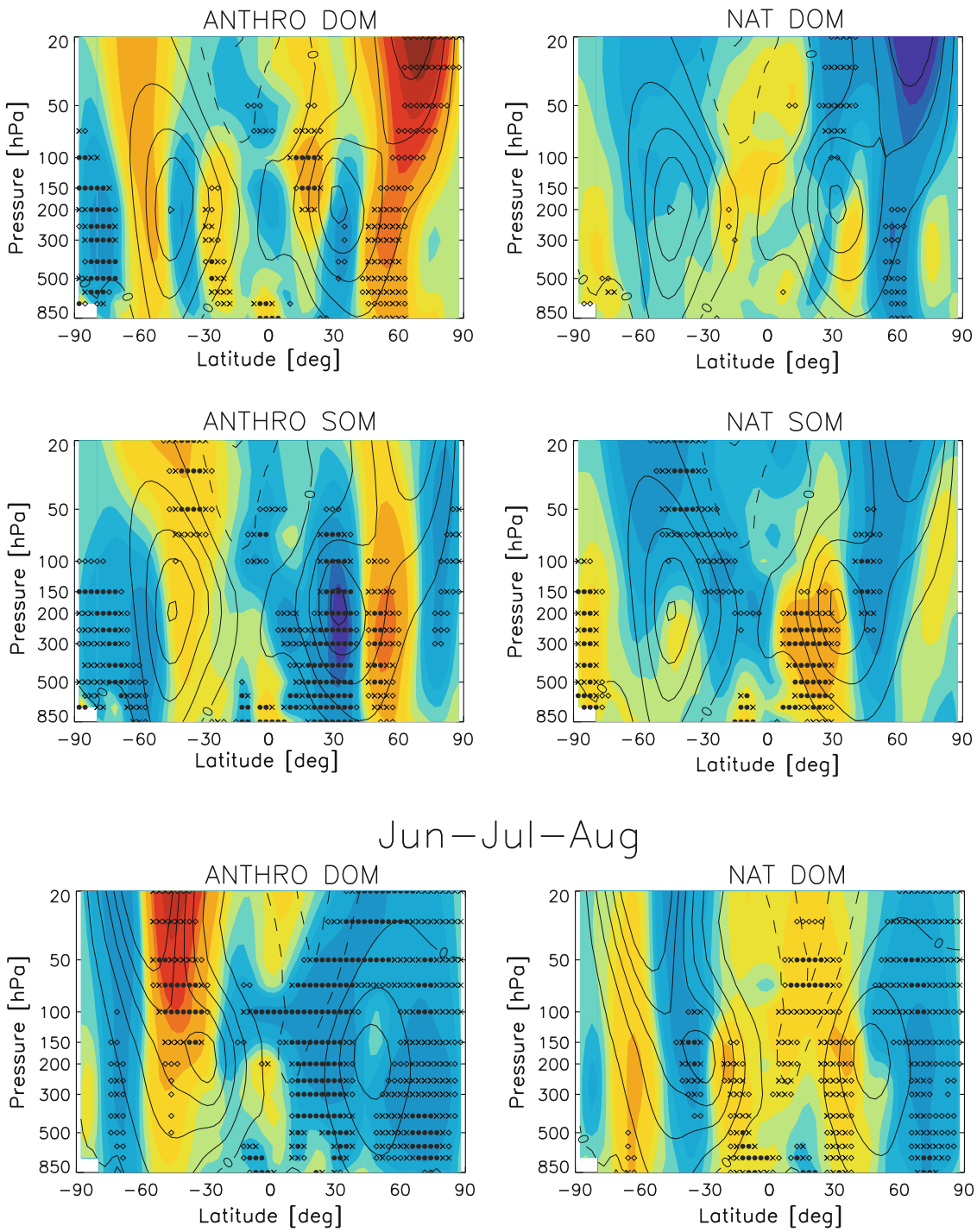

Jul-Aug
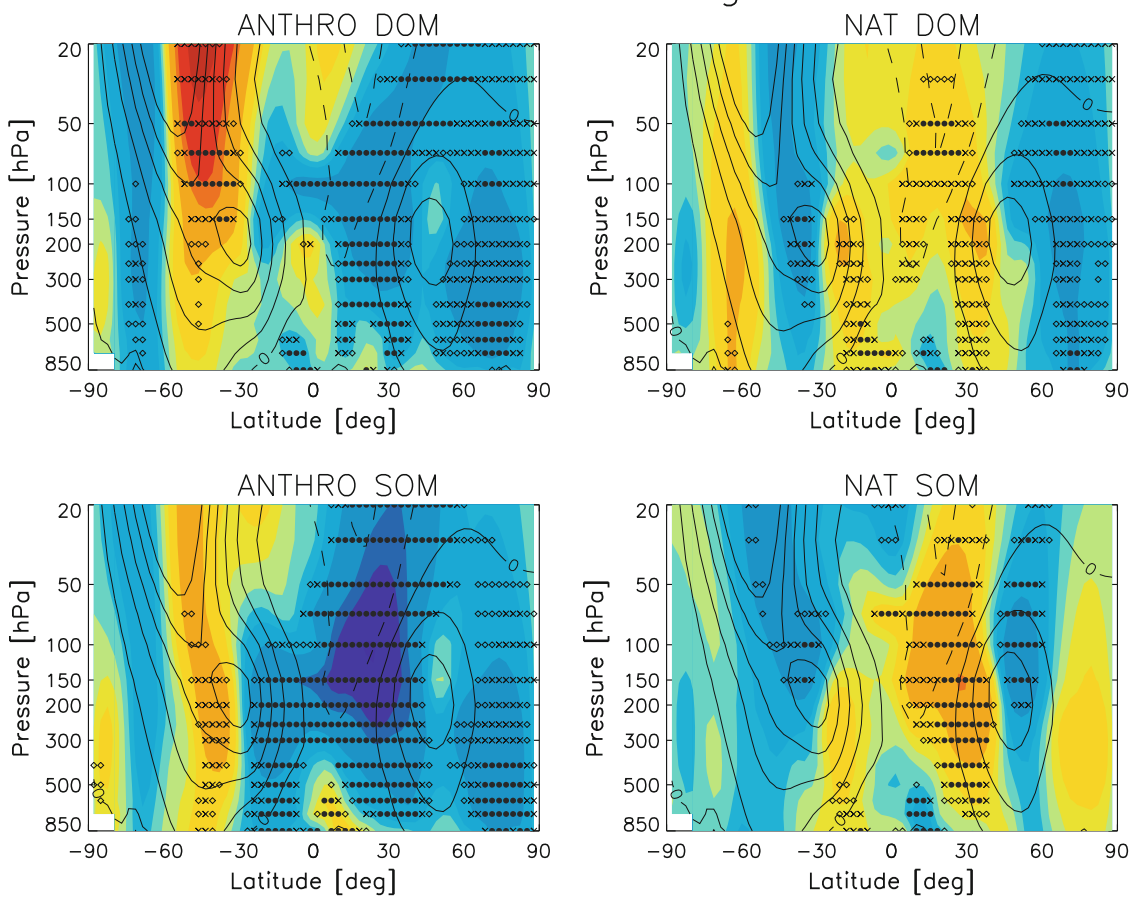

stratosphere forces the jets equatorward, while low-latitude stratospheric heating forces the jets poleward. Equatorward displacement of the jets in response to a warmer stratosphere was also found by Williams (2006).
Our aerosol experiments are generally consistent with these relationships. For example, Fig. 6 shows that ANTHRO SOM yields an increase in the JJA tropopause height/decrease in tropopause pressure [based on a thermal 
Table 3 Poleward displacement of the NH and SH subtropical jet stream (STJ), subtropical mean meridional mass circulation minima (MMC), and subtropical precipitation minus evaporation $(\mathrm{P}-\mathrm{E}$ ) transition for both SOM (top) and DOM (bottom) ocean boundary conditions

\begin{tabular}{|c|c|c|c|c|c|c|c|c|c|}
\hline & \multicolumn{3}{|l|}{ DJF } & \multicolumn{3}{|l|}{ JJA } & \multicolumn{3}{|l|}{ ANN } \\
\hline & STJ & MMC & $P-E$ & STJ & MMC & $P-E$ & STJ & MMC & $P-E$ \\
\hline \multicolumn{10}{|l|}{ SOM } \\
\hline \multicolumn{10}{|l|}{$\mathrm{NH}$} \\
\hline ANTHRO & -0.10 & $0.40 * *$ & $0.32 * *$ & 0.20 & $0.24 * *$ & 0.27 & 0.17 & 0.02 & $0.27 *$ \\
\hline NAT & -0.18 & $-0.20 *$ & $-0.26 * *$ & -0.22 & $-0.19 *$ & -0.23 & -0.16 & -0.02 & -0.22 \\
\hline UHT & 0.28 & 0.05 & 0.29 & -0.48 & $-0.43^{*}$ & 0.70 & -0.11 & -0.23 & 0.33 \\
\hline \multicolumn{10}{|l|}{ SH } \\
\hline ANTHRO & -0.12 & $-0.46^{* *}$ & -0.07 & 0.27 & 0.13 & 0.11 & -0.02 & 0.36 & -0.02 \\
\hline NAT & -0.14 & $0.39 * *$ & -0.01 & -0.15 & $-\mathbf{0 . 1 3}$ & -0.06 & -0.03 & -0.06 & -0.01 \\
\hline UHT & -0.42 & -0.48 & 0.05 & -0.46 & -0.11 & 0.37 & -0.37 & -0.41 & $0.21 *$ \\
\hline \multicolumn{10}{|l|}{ DOM } \\
\hline \multicolumn{10}{|l|}{$\mathrm{NH}$} \\
\hline ANTHRO & -0.12 & 0.09 & 0.13 & 0.28 & $0.29 * *$ & -0.49 & 0.20 & $-\mathbf{0 . 3 0}$ & -0.11 \\
\hline NAT & 0.11 & 0.11 & 0.06 & -0.18 & -0.12 & -0.26 & -0.11 & 0.20 & -0.11 \\
\hline \multicolumn{10}{|l|}{ SH } \\
\hline ANTHRO & 0.19 & -0.09 & -0.03 & 0.05 & $0.17 *$ & -0.05 & 0.11 & $\mathbf{0 . 7 2} * *$ & 0.04 \\
\hline NAT & 0.08 & 0.08 & 0.04 & -0.17 & -0.06 & 0.13 & 0.04 & -0.32 & 0.05 \\
\hline
\end{tabular}

The $\mathrm{P}-\mathrm{E}$ transition is defined as the latitude where $\mathrm{P}-\mathrm{E}$ changes from negative to positive on the poleward sides of the the subtropical minima. Significance is denoted by bold $(\geq 90 \%) ; *(\geq 95 \%)$ and $* *(\geq 99 \%)$. Units are degrees latitude

definition according to Reichler et al. (2003)], whereas NAT SOM yields a decrease in JJA tropopause height (other seasons are similar). Furthermore, ANTHRO SOM yields an increase in JJA gross dry static stability; NAT SOM yields a decrease. Over all aerosol experiments and seasons, the correlation between the poleward jet displacement and $30^{\circ} \mathrm{N} / \mathrm{S}$ tropopause height change is 0.76 , significant at the $99 \%$ confidence level. Similarly, the correlation between $\Delta \phi_{\text {jet }}$ and the mid-latitude $\left(30^{\circ}-50^{\circ}\right)$ gross dry static stability change is 0.78 , also $99 \%$ significant. The jet displacements are also associated with shifts of the climatological mid-latitude baroclinicity $(d T / d Y)$ maxima near the jet altitude $(300 \mathrm{hPa})$, with poleward displacement for ANTHRO and equatorward displacement for NAT, an expected consequence from thermal wind balance. However, Fig. 6 shows that these changes tend to be localized near the latitude of the jets, suggesting a response, rather than a cause. This is further supported by comparing $\Delta d T / d Y$ to $\left(\Delta \phi_{\text {jet }}\right) \times\left(d^{2} T / d Y^{2}\right)$ (not shown), with the second derivative of temperature based on the control integration. For UHT, $\Delta d T / d Y$ is consistently larger than $\left(\Delta \phi_{\text {jet }}\right) \times\left(d^{2} T / d Y^{2}\right)$, which suggests the temperature forcing is dragging the jet. In contrast, the aerosol experiments feature a $\Delta d T / d Y$ that is comparable to $\left(\Delta \phi_{\text {jet }}\right) \times\left(d^{2} T / d Y^{2}\right)$, suggesting displacement of the temperature field along with the jet.
Figure 7, however, shows that $\Delta \phi_{\text {jet }}$ is consistent with the meridional net aerosol forcing (i.e. $F_{\mathrm{ATM}}+F_{\mathrm{SFC}}$ ) gradient $\left(d F_{\mathrm{NET}} / d Y\right)$ between the subtropics and midlatitudes $\left(20^{\circ}-50^{\circ}\right)$. The relationship is robust across experiments and seasons for both the $\mathrm{NH}$ and $\mathrm{SH}$, with a correlation of 0.50 , significant at the $99 \%$ confidence level. For the $\mathrm{NH}$ only, the correlation coefficient increases to 0.65 ; similarly, the relationship improves to 0.60 based on DJF, JJA and ANN only. Similar results are obtained with other subtropical/midlatitude boundaries. This relationship indicates that a more positive $F_{\mathrm{NET}}$ on the equatorward flank of the jet is associated with jet expansion (ANTHRO), or alternatively, that a less positive $F_{\mathrm{NET}}$ on the equatorward flank of the jet is associated with jet contraction (NAT). One possible explanation is that expansion of the tropics is a mechanism to increase the heat transported to midlatitudes. Note, however, that $d F_{\mathrm{NET}} / d Y$ explains only $25 \%$ of the variance of $\Delta \phi_{\text {jet }}$, which suggests other mechanisms-possibly related to stratospheric $\Delta T$ may be important.

Similar to what occurs with greenhouse gas (GHG) (e.g. Kushner et al. 2001; e.g. Raisanen 2003) and IPCC AR4 (e.g. Lorenz and DeWeaver 2007) experiments, both UHT jets rise and strengthen (not shown). This is consistent with maximum warming in the tropical upper troposphere, leading to a higher tropopause and an increase in meridional 

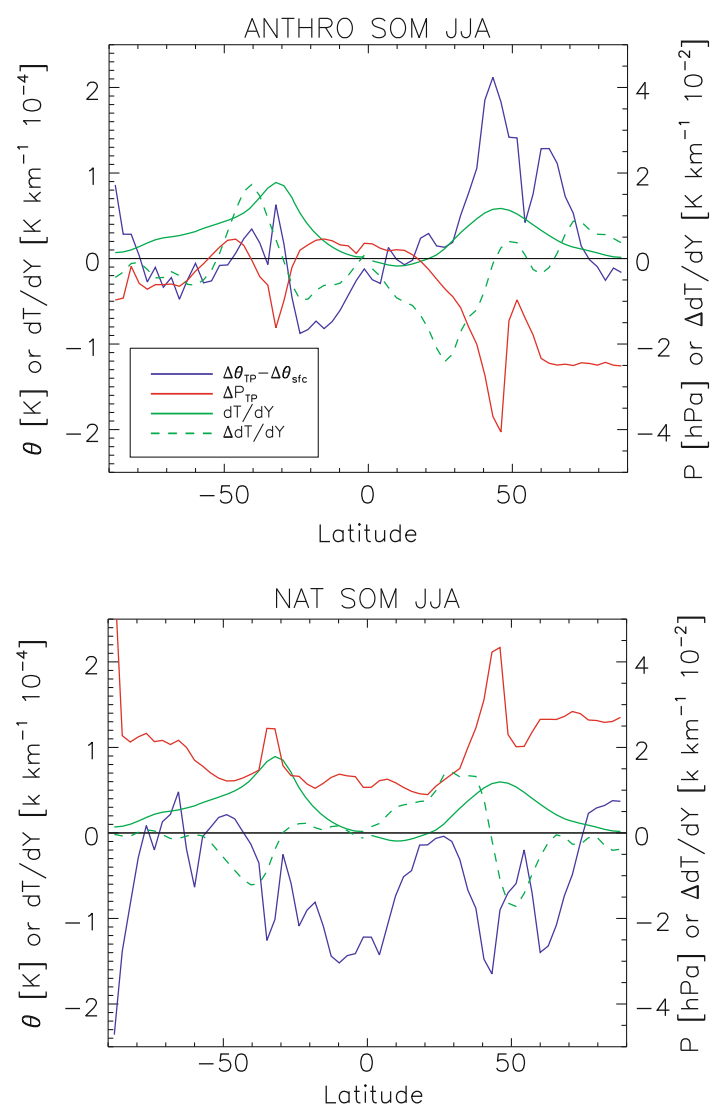

Fig. 6 Zonal JJA gross dry static stability change (blue; $\left.\Delta \theta_{\mathrm{TP}}-\Delta \theta_{\mathrm{sfc}}\right)$, tropopause pressure change $\left(\right.$ red $\left.; \Delta P_{\mathrm{TP}}\right)$, climatological baroclinicity at $300 \mathrm{hPa}$ (green solid; dT/dY) and the corresponding response (green dashed; $\Delta d T / d Y$ ) for ANTHRO SOM (top) and NAT SOM (bottom). Northern hemisphere baroclinicity, and the response, have been multiplied by -1 so that positive values represent colder air poleward

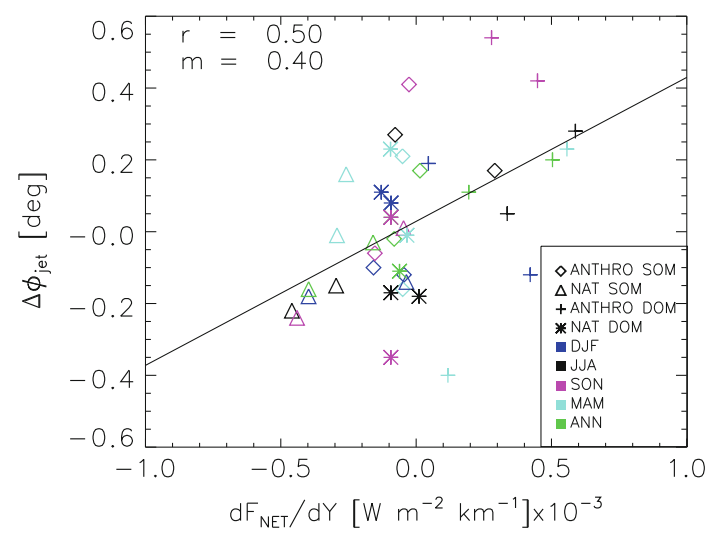

Fig. 7 Scatterplot of the poleward jet displacement $\left(\Delta \phi_{\text {jet }}\right.$; degrees latitude) versus the meridional net aerosol forcing gradient $\left(d F_{\mathrm{NET}} /\right.$ $d Y$ ) averaged over $20-50^{\circ}$ for each aerosol experiment, hemisphere and season (DJF, JJA, SON, MAM and ANN). NH $d F_{\mathrm{NET}} / d Y$ values have been multiplied by -1 so that positive values represent more positive $F_{\mathrm{NET}}$ at lower latitudes. Also shown is the correlation coefficient $(r)$ and the corresponding best fit line and slope $(m)$. Net aerosol forcing is estimated as $F_{\mathrm{ATM}}+F_{\mathrm{SFC}}$, with surface forcing over ocean grid points set to zero for the DOM experiments temperature gradient. By the thermal wind equation, this implies an increase in westerlies. Global warming experiments, however, also feature poleward displacement of the subtropical jets (Seidel et al. 2008), which is opposite the contraction that occurs with UHT (Table 3). Because UHT and GHG experiments feature similar tropospheric warming patterns, we suspect the dissimilar jet response is due to the different stratospheric temperature response. We are currently exploring this GHG-UHT difference, and others, in more detail.

\subsubsection{Mid/high-latitude response}

Aerosol also have a significant affect on zonal winds outside the tropics. Figure 5 shows the ANTHRO DOM run exhibits a significant increase in wind near $60^{\circ} \mathrm{N}$ in DJF throughout the troposphere and lower stratosphere, with a decrease near $30^{\circ} \mathrm{N}$; an opposite pattern is forced by NAT. Moreover, Fig. 8 shows that NAT and ANTHRO, particularly for the DOM experiments, exhibit opposite DJF sea-level pressure changes $\left(\Delta P_{\mathrm{SL}}\right)$ at high $\mathrm{NH}$ latitudes. For NAT DOM, $\Delta P_{\mathrm{SL}}$ is positive poleward of $50^{\circ} \mathrm{N}$, peaking at $1.7 \mathrm{hPa}$ near $90^{\circ} \mathrm{N}$. For ANTHRO DOM, however, $\Delta P_{\mathrm{SL}}$ is negative poleward of $50^{\circ} \mathrm{N}$, peaking at $-2 \mathrm{hPa}$. A similar, but even larger, response occurs during MAM, with $\Delta P_{\mathrm{SL}}$ peaking at $1.9 \mathrm{hPa}$ for NAT DOM and $-3 \mathrm{hPa}$ for ANTHRO DOM (not shown). These changes are reminiscent of the positive and negative AO (Thompson and Wallace 2000), respectively, and are associated with $\Delta T$ and the propagation of wave activity (see next section). The ANTHRO changes are similar to those reported by Chung and Ramanathan (2003), who found that Indian aerosols drove zonal wind changes consistent with the positive AO.

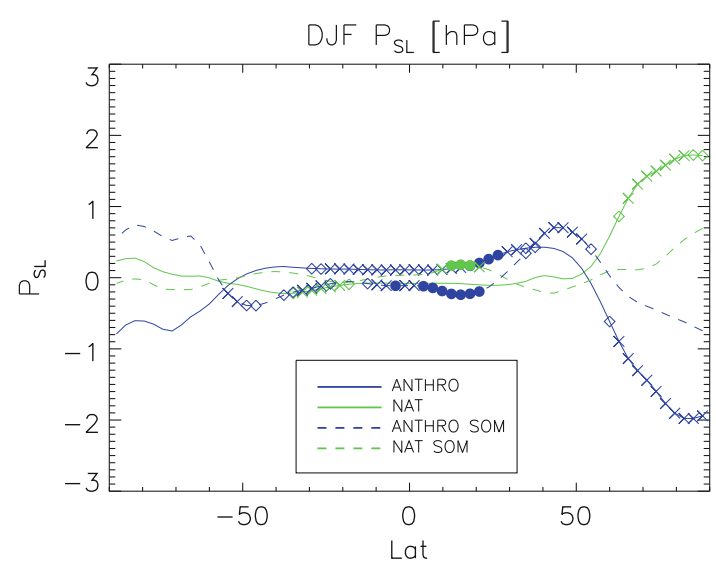

Fig. 8 DJF sea level pressure change. Units are hPa. Symbols represent significance as in Fig. 2 

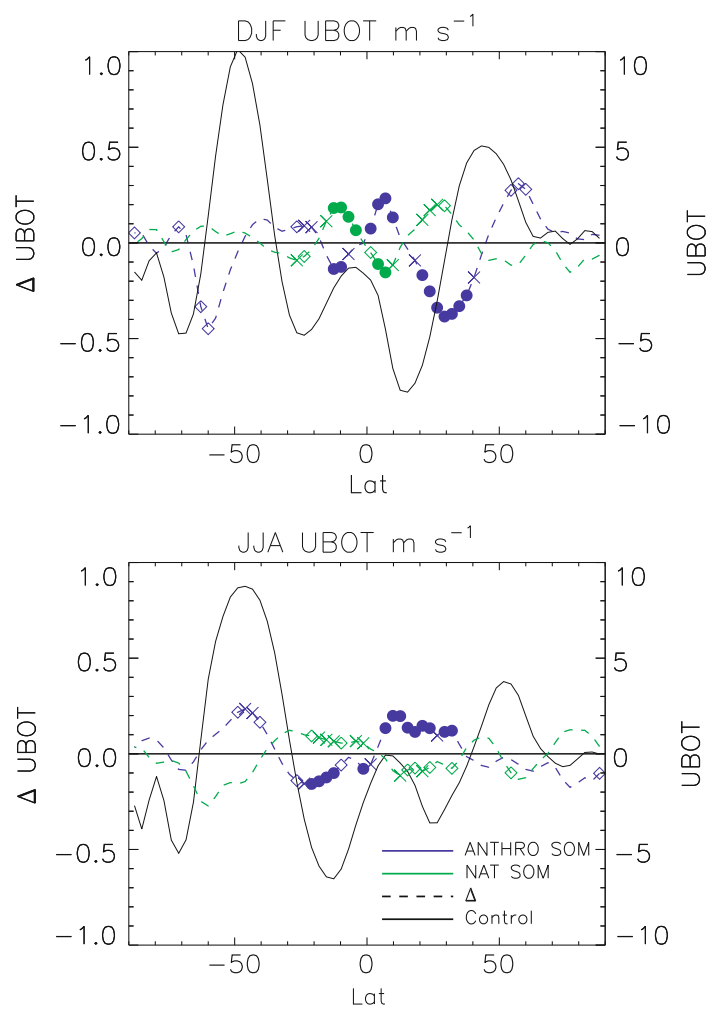

Fig. 9 As in Fig. 4, except for zonal wind at the model's bottom level (UBOT)

In addition to the troposphere/stratosphere wind changes, aerosols affect mid/high-latitude winds near the surface, a measure of the storm tracks. Figure 9 shows the zonal wind at the model's bottom level (UBOT) and the corresponding change, for the SOM experiments during DJF and JJA. During DJF in the NH, ANTHRO shifts the storm track poleward, while NAT shifts it southward, consistent with the above analysis. DOM results (not shown) are very similar. The corresponding SOM changes during austral winter (JJA) are less distinct, but show anthropogenic aerosols yield a strengthening and slight poleward shift the SH wintertime storm track, with non-significant changes for natural aerosols. The ANTHRO results are similar to GHG experiments of the twenty-first century, which exhibit intensification and a poleward shift of the storm tracks in both hemispheres during DJF and in the $\mathrm{SH}$ during JJA (Yin 2005).

\section{Understanding the high latitude response}

Changes in the AO associated with changed climates have previously been explained by changes in wave propagation and/or refractive index of the atmosphere (e.g., Rind et al. 2005). Under quasi-geostrophic scaling, the northward $\left(F_{y}\right)$ and vertical $\left(F_{z}\right)$ Eliassen-Palm (EP) flux $(\mathbf{F})$, which are proportional to the meridional and vertical zonal average wave energy flux (Holton 1992), is

$F_{y}=-\rho \overline{u^{\prime} v^{\prime}}, \quad F_{z}=\frac{\rho f R_{d} \overline{v^{\prime} T^{\prime}}}{N^{2} H}$

where $\overline{u^{\prime} v^{\prime}}$ is the meridional eddy momentum flux, $\overline{v^{\prime} T^{\prime}}$ is the eddy northward heat flux, $N$ is the Brunt-Vaisala frequency, $R_{d}$ is the dry air gas constant, $H$ is the scale height, $f$ is the Coriolis parameter and $\rho$ is the air density. Figure 10 shows the DJF change in EP flux and flux divergence, divided by the standard density. The changes are largest for the DOM (fixed-SST) signals, with consistently opposite changes for NAT and ANTHRO forcings. NAT shows upward and poleward wave energy propagation, peaking between 40 and $60^{\circ} \mathrm{N}$. This is consistent with a decrease in wave refraction, defined as the ratio of the meridional and vertical EP flux [the meridional turning relative to the upward energy flux, as in Rind et al. (2005)]. The average $\mathrm{NH}$ percent change in wave refraction is $-6.5 \%$ for NAT DOM and $-3.7 \%$ for NAT SOM (18 and $10.2 \%$, respectively, for ANTHRO). NAT forcing also yields anomalous F convergence above $200 \mathrm{hPa}$ and poleward of $40^{\circ} \mathrm{N}$. This suggests an increase in westward momentum deposition (i.e., wave drag), inducing a torque that decelerates the winds. ANTHRO changes are again consistently opposite to these.

A spectral analysis indicates that $\Delta F_{z}$ arises mainly from zonal wavenumbers 1-4 (Fig. 11). For both DOM runs, $\Delta F_{z}$ is mainly composed of zonal wavenumber 2 , while for SOM, the response is dominated by wavenumber 3 for NAT forcing and shows no dominant component for ANTHRO forcing. By the Charney-Drazin theory (e.g., Andrews et al. 1987), the horizontal length scale of planetary waves controls the extent to which they can propagate into the stratosphere. This suggests that wave energy was better able to penetrate into the stratosphere in the DOM experiments due to the longer wavelength of the response, explaining the stronger AO-like changes near the surface in those runs.

The reason for the prominence of wavenumber 2 in the DOM response is likely because this wavenumber is also prominent in the net aerosol forcing at mid-latitudes $\left(30-60^{\circ} \mathrm{N}\right)$, where in DOM, net forcing over oceans includes only the atmospheric heating part. The DOM net forcing is near zero over the Pacific and Atlantic Oceans, but has negative maxima at two approximately opposite longitudes: in the India/SE Asia and North America regions. In the SOM experiments, however, the net aerosol forcings are negative over both oceans and land. This is especially true for ANTHRO because of the more complicated geographical pattern of the anthropogenic aerosol amount and optical properties. 
Fig. 10 DJF EP flux $\left(\mathrm{m}^{2} \mathrm{~s}^{-2}\right)$ and EP flux divergence $\left(10^{-6} \mathrm{~m}\right.$ $\mathrm{s}^{-2}$ ) change, divided by the standard density. Contour interval is $\{-6,-4,-2$, $-1,0,1,2,4,6\}$
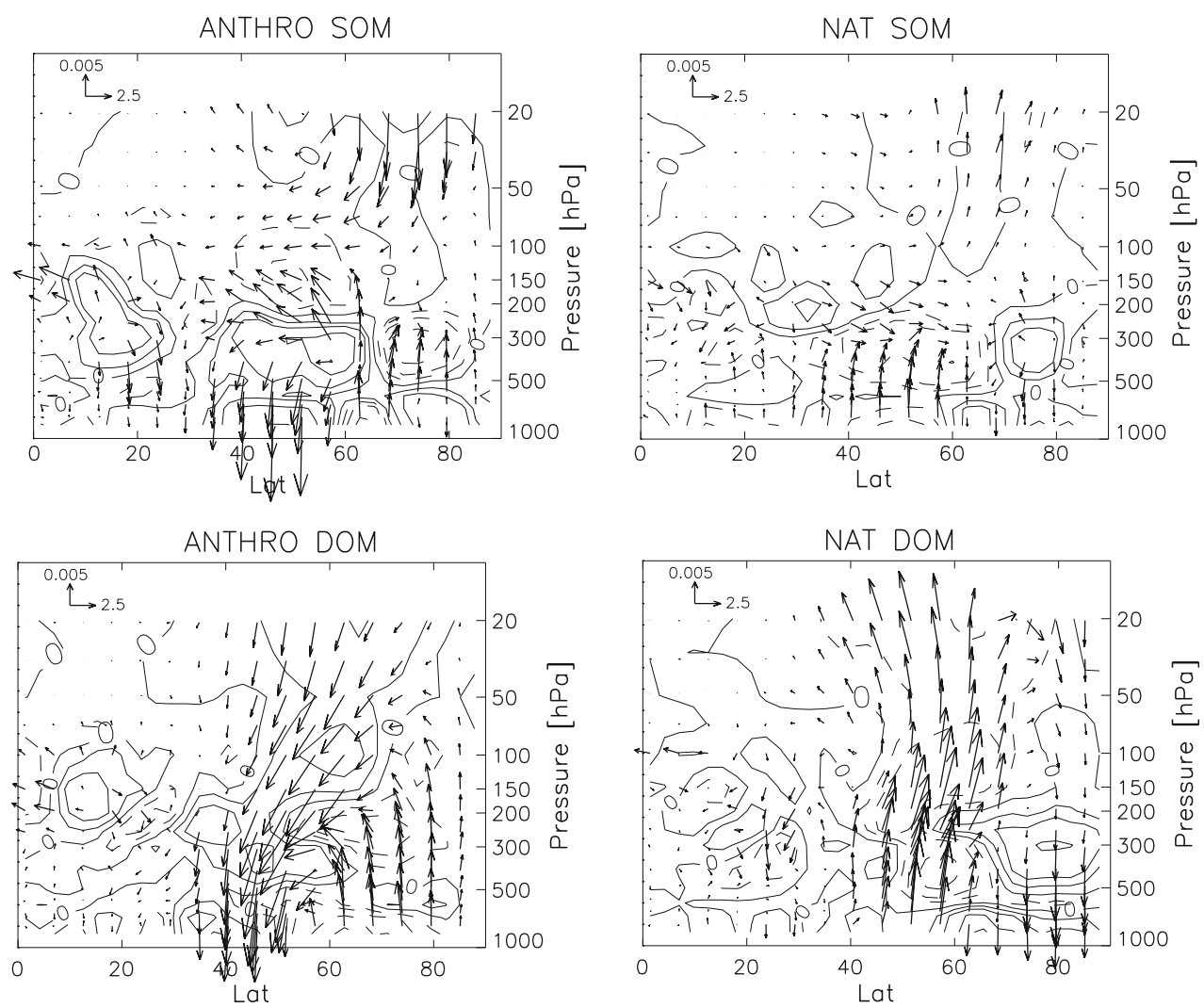

The increased wave drag in NAT is associated with increased poleward transport of air in the middle stratosphere and subsidence in the lower stratosphere. This hydrostatically leads to increased mass and $P_{\mathrm{SL}}$ at high latitudes (Fig. 8). The increased subsidence also leads to adiabatic compression, increasing temperatures in the lower stratosphere at high latitudes (Fig. 2). By thermal wind balance, this reduced meridional temperature gradient implies a decrease in the strength of the westerlies in the mid-stratosphere (Fig. 5). This weakened shear suggests less refraction of planetary wave energy. Since planetary waves are propagating up from the surface, there is less refraction by the decreased vertical shear below the area of reduced zonal wind. Less refraction of planetary wave energy at the lower boundary of the wind anomaly leads to wave convergence (Fig. 10) and a deceleration of the zonal wind in that area. Over time, the wind anomaly propagates downward from the mid-stratosphere to the troposphere (Haynes et al. 1991; Shindell et al. 2001; Stenchikov et al. 2002; Song and Robinson 2004). Opposite changes occur with ANTHRO.

The EP flux changes are consistent with the tropospheric temperature changes, where an increase in $\nabla T$ suggests an increase in mean zonal energy and amplitude of planetary waves (Stenchikov et al. 2002). For DOM, both ANTHRO and NAT forcings warm the tropical troposphere due to the imposed aerosol heating. However, NAT cools near $40^{\circ} \mathrm{N}$, resulting in a stronger meridional $\nabla T$; ANTHRO warms most near $40^{\circ} \mathrm{N}$, resulting in a weaker meridional $\nabla T$. Similar meridional $\Delta \nabla T$ exist for the SOM signals.

Figure 12 shows the changes in geopotential height, temperature and horizontal winds at $500 \mathrm{hPa}$ for both DOM runs. The aerosol heating induces local circulation changes in the mid-latitudes, concentrated into four centers near $40^{\circ} \mathrm{N}$ : the central Pacific Ocean, North America, the eastern Atlantic Ocean and northeast China/Japan (these centers also occur in the SOM experiments). The latter two teleconnections resemble those Kim et al. (2006) find during MAM. With NAT forcing these centers are associated with lower geopotential heights, counterclockwise circulation anomalies and colder temperatures. The latter are associated with both cold-air advection and adiabatic cooling of ascending air (not shown). Midlatitude cooling yields a greater $\nabla T$, which is associated with increased zonal mean energy and amplitudes of tropospheric planetary wave, and increased wave flux activity into the lower stratosphere. These results are similar to those of Stenchikov et al. (2002), where the tropospheric cooling effect of volcanic aerosols decreases $\nabla T$ between 30 and $60^{\circ} \mathrm{N}$, resulting in decreased vertical wave activity flux and circulation changes consistent with the positive AO. 
Fig. 11 DJF change in the vertical component of the EP flux $\left(10^{-3} \mathrm{~m}^{2} \mathrm{~s}^{-2}\right)$ at $600 \mathrm{hPa}$ divided by the standard density (black line). Also included is the contribution to $\Delta F_{z}$ from each of the four leading zonal wavenumbers (colored lines)
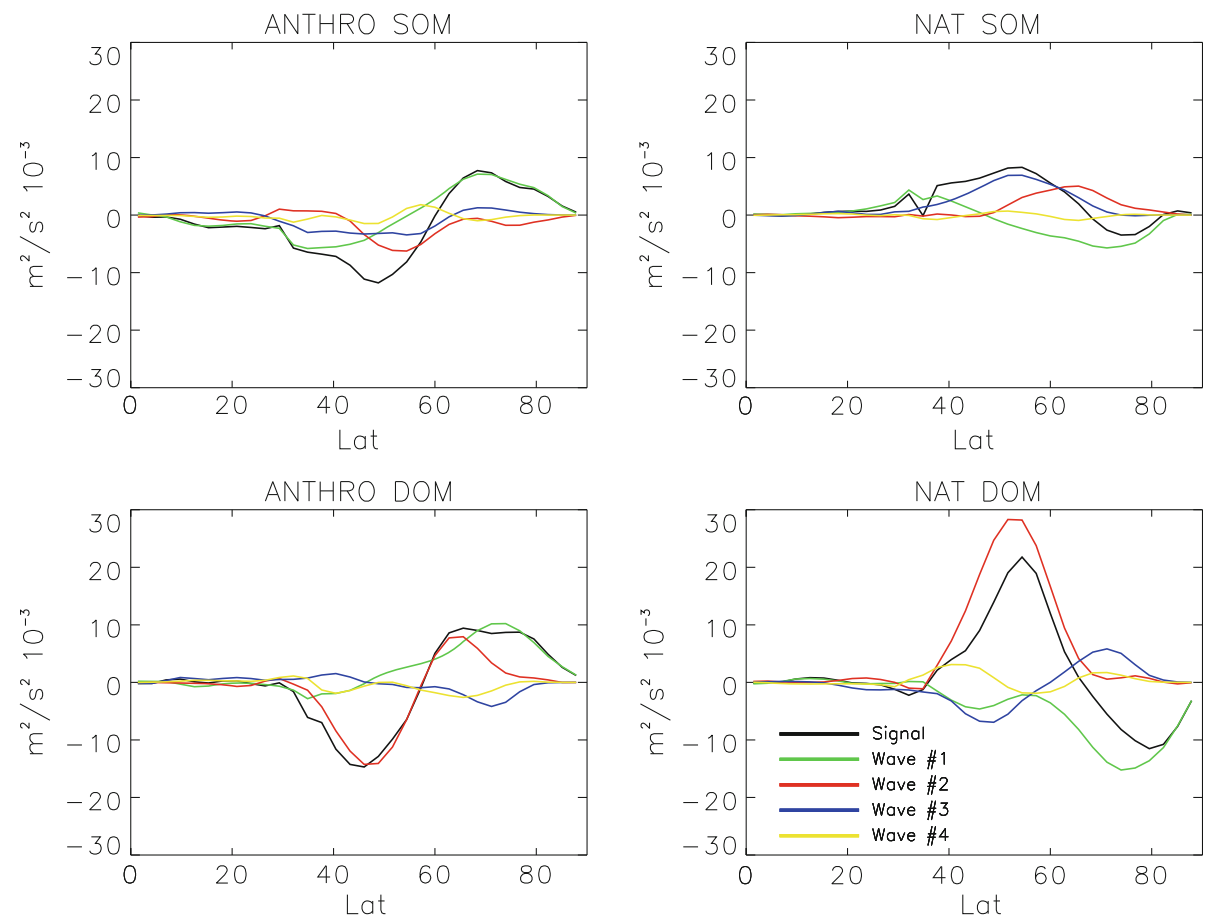

Our attribution of the AO-like changes to the spatial heterogeneity of the aerosol forcing-and resulting low/ mid latitude $\Delta \nabla T$-is also supported by the changes in the UHT experiment, where changes in low/mid-latitude $\nabla T$ and the AO were both negligible. As mentioned above, however, the vertical profile of UHT warming in the troposphere is similar to GHG experiments, which generally exhibit positive AO changes (Shindell et al. 2001; Gillett et al. 2002; Osborn 2004; Rauthe et al. 2004), as do IPCC models with both GHGs and sulfate aerosols (Miller et al. 2006). Such an AO trend is generally explained by an increase in stratospheric $\nabla T$, which produces stronger midlatitude zonal winds that tend to inhibit propagation of planetary waves into the polar stratosphere (Stenchikov et al. 2002). The lack of a UHT AO signal, therefore, appears to be related to the dissimilar zonal wind response, with negligible increases in mid-latitude UHT $U$ during DJF.

\section{Conclusions}

We used the Community Atmosphere Model (CAM3) to investigate the equilibrium climate response to anthropogenic and natural aerosols, focusing on atmospheric circulation changes. To avoid the uncertainties and known underestimation of directly simulated absorbing aerosol forcing (Sato et al. 2003; Ramanathan and Carmichael 2008; Koch et al. 2009), we directly incorporated the aerosol direct effect (i.e., absorption and reflection of solar radiation) estimated from the model-assisted data analysis of Chung et al. (2005). Their estimated topof-atmosphere, direct, clear-sky forcing $\left(3.4 \mathrm{~W} \mathrm{~m}^{-2}\right)$ is nearly three times the average $\left(1.24 \mathrm{~W} \mathrm{~m}^{-2}\right)$ reported from GCMs by Forster et al. (2007). To help determine the importance of oceans in communicating forcing responses back to the atmosphere we repeated each forcing experiment with both climatological SSTs and a slab ocean model. Results show that aerosols affect the circulation at all latitudes, with natural (mostly reflecting) and anthropogenic (mostly absorbing) aerosols driving changes to the circulation that are qualitatively similar but of opposite sign. Despite the geographically uneven forcing, the planetary-scale responses appear to be attributable to the zonal-mean (or in some cases lowwavenumber) aspects of the forcing.

An important caveat to our study is that anthropogenic aerosols are a mixture of at least two types (sulfate and black carbon) that have very different optical properties, and at present seem to occur in a proportion so as to exert a relatively small net top-of-atmosphere radiative effect. We anticipate based on our results that anthropogenic sulfate would, by itself, have planetary-scale impacts similar to those of natural aerosols (both having high single-scatter albedo) despite their somewhat different regional patterns. Given the above, and the finding here of nearly opposite effects of anthropogenic and natural aerosols, we infer that black carbon alone would have significantly stronger impacts than found in our anthropogenic aerosol experiments. Since the relative amounts of sulfate and black carbon have changed significantly over time, decadal variations in aerosol forcing and response may well have 

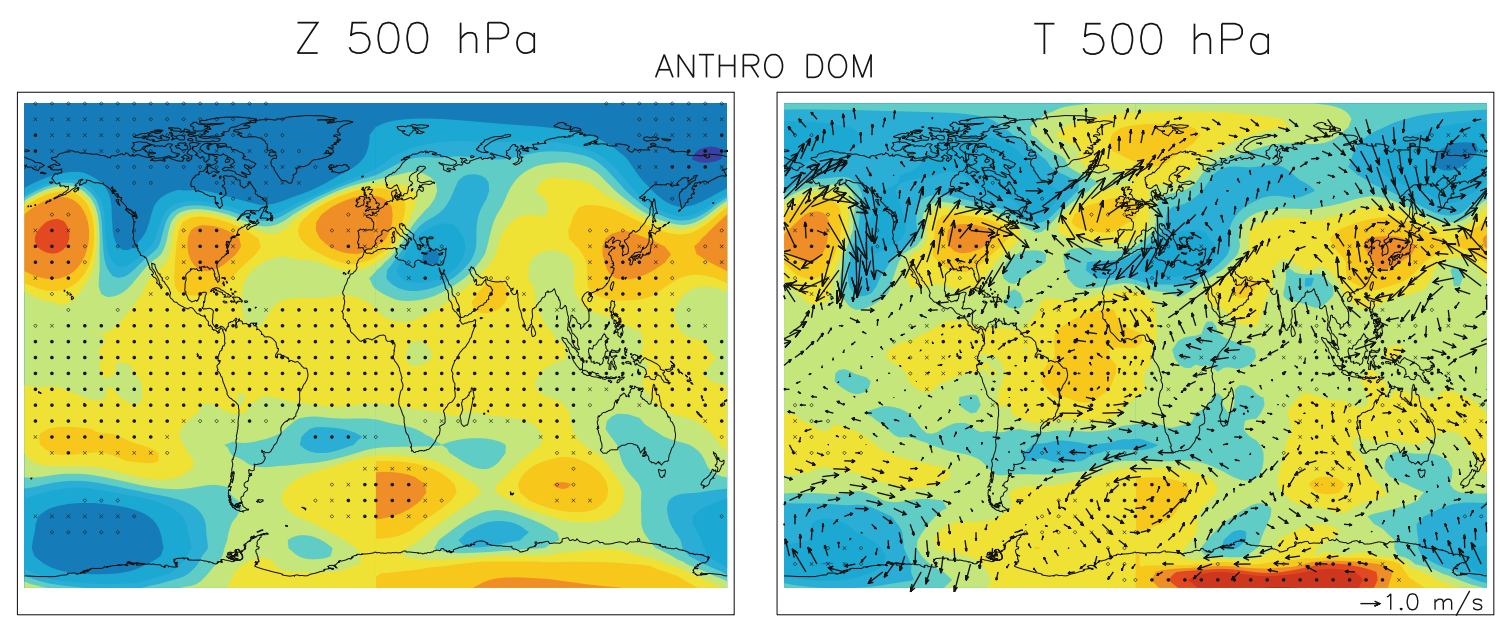

NAT DOM

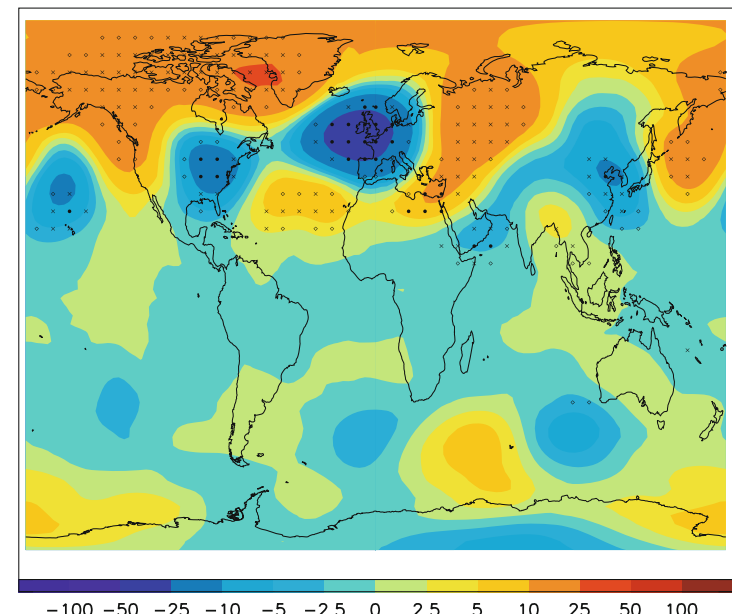

$\begin{array}{lllllllllllll}-100 & -50 & -25 & -10 & -5 & -2.5 & 0 & 2.5 & 5 & 10 & 25 & 50 & 100\end{array}$

Fig. 12 DJF geopotential height (left panel) and temperature (right panel) change at $500 \mathrm{hPa}$. Horizontal wind change $\left(\mathrm{m} \mathrm{s}^{-1}\right)$ is included with $\Delta T$. Symbols-which are plotted every other grid point to

exceeded those for either the present-day anthropogenic or natural aerosol. Further studies would be needed to test these assertions.

Due to the predominance of northern-hemisphere sources for both aerosol types considered, anthropogenic aerosols warmed the troposphere (and natural aerosols cooled it) more in the northern hemisphere than in the southern, with changes of order $0.1-0.3 \mathrm{~K}$ in the lower troposphere. Anthropogenic aerosols consequently shifted the ITCZ northward while natural aerosols shifted it southward. The northward shift is associated with a weakening of the DJF mean meridional mass circulation and strengthening of the JJA one, with opposite changes for the southward shift; all are consistent with the radiatively forced changes to inter-hemispheric temperature gradients. This behavior is consistent with other aerosol studies focusing on the direct effects of BC aerosols (Roberts and Jones 2004; Wang 2004, 2007; Chung and Seinfeld 2005;

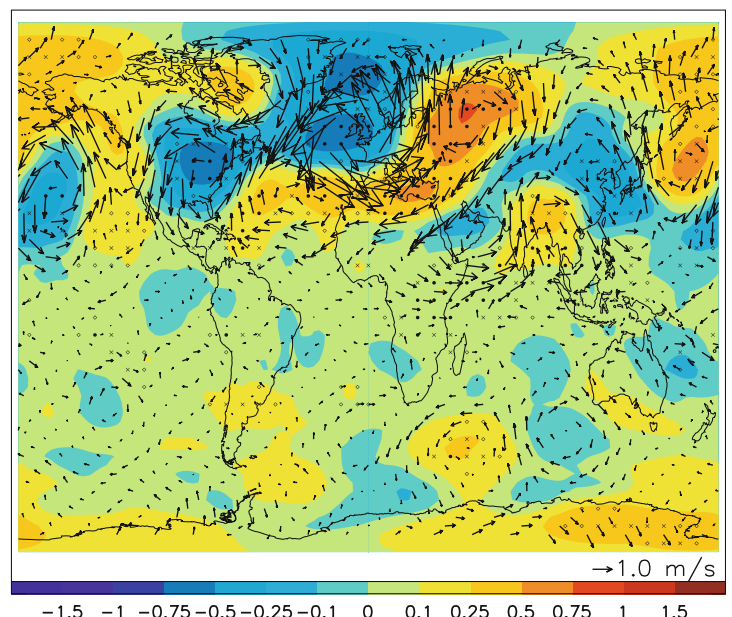

improve clarity-represent significance at the $90 \%$ (diamond), $95 \%$ (cross) and 99\% (dot) confidence level. Units are $\mathrm{m}$ and $\mathrm{K}$, respectively

Yoshimori and Broccoli 2008), and the direct (Yoshimori and Broccoli 2008) and indirect (Rotstayn et al. 2000; Williams et al. 2001) effects of sulfate aerosols. Changes in Hadley cell strength were smaller in the fixed-SST experiments because inter-hemispheric temperature gradients were not able to change as much. These results support previous findings that aerosols affect the variability of precipitation at low latitudes, for example in the Amazon (Cox et al. 2008) and the Sahel (Rotstayn and Lohmann 2002). Aerosol forcing is also associated with meridional shifts of the subtropical jets. In the slab-ocean experiments, anthropogenic aerosols move the subtropical jets poleward by $0.2^{\circ}-0.3^{\circ}$ each, leading to expansion of the tropics. Natural aerosols produce the opposite effect.

Global emissions of black carbon have generally increased over the latter half of the twentieth century, although they remain quite uncertain and have probably fallen somewhat since 1990 (Novakov et al. 2003; Ito and 
Penner 2005; Bond et al. 2007). Global emissions of sulfate aerosols, however, have been declining since the 1970s (van Aardenne et al. 2001; Smith et al. 2004). Our results indicate that both of these trends should have contributed to poleward migration of the subtropical jet in the $\mathrm{NH}$, and possibly in the $\mathrm{SH}$, hence contributing to the observed widening of the tropics from the 1970s through 1990 or so. In fact such widening has been observed (or inferred from stratospheric cooling and tropospheric warming trends), and is larger than predicted by models forced with GHGs and other forcings (Fu et al. 2006; Seidel et al. 2008; Johanson and $\mathrm{Fu}$ 2009). Although some of these models include aerosol forcing, aerosol absorption is likely underestimated (Sato et al. 2003; Koch et al. 2009). The observed widening of $2.0^{\circ}-4.8^{\circ}$ over 25 years, however, is much larger than reported here for either aerosol forcing $\left(\sim 0.5^{\circ}\right)$ and does not appear to have stopped in the last decade or two. Nonetheless, aerosols may have contributed non-negligibly to this widening and, as discussed above, impacts from past changes in anthropogenic aerosol composition could exceed those simulated here for the current composition.

Arctic oscillation-like changes result from altered tropospheric temperature gradients, which affect the vertical propagation of wave activity. We argue that this is because anthropogenic aerosols decrease temperature gradients between low and mid-latitudes, decreasing the vertically propagating wave activity and increasing equatorward refraction, with opposite impacts from natural aerosols. The increased refraction causes acceleration of the stratospheric zonal winds, which eventually propagates back down through the troposphere (Haynes et al. 1991; Shindell et al. 2001; Stenchikov et al. 2002; Song and Robinson 2004) where it manifests itself at the surface as sealevel pressure and temperature anomalies.

The result is zonal winds near $60^{\circ} \mathrm{N}$ increasing by $\sim 1 \mathrm{~m}$ $\mathrm{s}^{-1}$, temperatures in the high-latitude stratosphere decreasing by $(\sim 1 \mathrm{~K})$ and high-latitude sea-level pressure decreasing by $\sim 2 \mathrm{hPa}$, with anthropogenic aerosol forcing. Similar impacts occur in the simulation of Chung and Ramanathan (2003) for absorbing aerosols over India only. We found that changes were significant only with fixed SSTs, apparently because longer wavelength planetary waveswhich are better able to penetrate into the stratosphere-are preferentially excited by the imposed net aerosol forcing in this case due to the land-ocean distribution in the northern hemisphere. Regionally restricted forcings could excite a similar response even with interactive oceans.

Because the high-latitude AO impacts are strong only with fixed SSTs, they do not appear to be robust to variations in ocean behavior, and fixed-SST results are unlikely to represent very well the impacts of trends in aerosols where the ocean has plenty of time to respond to flux changes at the surface. Moreover, the observed changes are significantly larger than those reported here even with fixed SST: from 1965 to 1995 , mean sea-level pressure north of $45^{\circ} \mathrm{N}$ dropped by $2.5 \mathrm{hPa}$ relative to that from $45^{\circ} \mathrm{N}$ to the equator (Gillett 2005), compared with a peak response here of $0.4 \mathrm{hPa}$. Similarly, zonal wind increased by $7 \mathrm{~m} \mathrm{~s}^{-1}$ at $60^{\circ} \mathrm{N}$ and $50 \mathrm{hPa}$ (Scaife et al. 2005), compared to roughly $1 \mathrm{~m} \mathrm{~s}^{-1}$ here. Thus, we find wind and pressure changes that occur in roughly the same ratio as those of recent hard-toexplain trends, but at much smaller magnitudes.

Nonetheless, the decadal variability in aerosol forcing (e.g., SE Asian haze Ramanathan et al. 2001b; e.g., Chung and Ramanathan 2003) - as opposed to, say, the more monotonically changing forcing by greenhouse gasesmakes it an interesting possibility for explaining variations in the AO, which also have a strong decadal nature (Feldstein 2002). Given the cancellation found here between absorbing and scattering aerosol impacts, it is possible that decadal changes in the ratio of black carbon to sulfate could have exerted large effects. It is also possible that shifts of emissions from one region to another (Streets et al. 2009) may have affected the $\mathrm{AO}$ by influencing $\nabla T$ and the wavelength of perturbations to the midlatitude flow. It would appear worthwhile to include more realistic aerosol forcing changes in climate models, or at least to consider more seriously the possible impacts of unknown variations in the distribution and type of aerosols as an additional source of forcing uncertainty in model experiments.

Acknowledgments This study was funded by the NSF (CAREER ATM-0453639), Yale University, and by NSF ARC-0714088 and NASA NNX07AR23G, UC Irvine. We thank Chul Eddy Chung for kindly providing his aerosol data set and for other useful suggestions, Charlie Zender for providing computing resources at UC Irvine, and Dorothy Koch and V. Ramanathan for useful suggestions. Part of this manuscript contributed to RJA's PhD thesis.

Open Access This article is distributed under the terms of the Creative Commons Attribution Noncommercial License which permits any noncommercial use, distribution, and reproduction in any medium, provided the original author(s) and source are credited.

\section{References}

Ackerman AS, Toon OB, Stevens DE, Heymsfield AJ, Ramanathan V, Welton EJ (2000) Reduction of tropical cloudiness by soot. Science 288:1042-1047

Albrecht BA (1989) Aerosols, cloud microphysics, and fractional cloudiness. Science 245:1227-1230

Allen RJ, Sherwood SC (2010) The aerosol-cloud semi-direct effect and land-sea temperature contrast in a GCM. Geophys Res Lett. 37:L07702. doi:10.1029/2010GL042759

Anderson TL, Wu Y, Chu DA, Schmid B, Redemann J, Dubovik O (2005) Testing the MODIS satellite retrieval of aerosol finemode fraction. J Geophys Res 110(D18204). doi:10/1029/2005 JD005978 
Andrews DG, Holton JR, Leovy CB (1987) Middle atmosphere dynamics. Elsevier, New York, pp 489

Bellouin N, Boucher O, Haywood J, Reddy MS (2005) Global estimates of aerosol direct radiative forcing from satellite measurements. Nature 438:1138-1141

Bollasina M, Nigam S, Lau K-M (2008) Absorbing aerosols and summer monsoon evolution over South Asia: an observational portrayal. J Clim 21:3221-3239

Bond TC, Bhardwaj E, Dong R, Jogani R, Jung S, Roden C, Streets DG, Trautmann NM (2007) Historical emissions of black and organic carbon aerosol from energy related combustion, 1850-2000. Global Biogeochem Cycles 21(GB2018). doi: 10.1029/2006GB002840

Broccoli AJ, Dahl KA, Stouffer RJ (2006) Response of the ITCZ to Northern Hemisphere cooling. Geophys Res Lett 33:L01702. doi: $10.1029 / 2005$ GL024546

Chin $\mathrm{M}$ et al (2002) Tropospheric aerosol optical thickness from the GOCART model and comparisons with satellite and sunphotometer measurements. J Atmos Sci 59:461-483

Chung C, Ramanathan V (2006) Weakening of the North Indian SST gradients and the monsoon rainfall in India and the Sahel. J Clim 19:2036-2045

Chung CE (2006) Steady vs. fluctuating aerosol radiative forcing in a climate model. J Korean Meteor Soc 42(6):411-417

Chung CE, Ramanathan V (2003) South Asian haze forcing: remote impacts with implications to ENSO and AO. J Clim 16:1791-1806

Chung CE, Ramanathan V, Kiehl JT (2002) Effects of the south Asian absorbing haze on the northeast monsoon and surface-air heat exchange. J Clim 15:2462-2476

Chung CE, Ramanathan V, Kim D, Podgorny IA (2005) Global anthropogenic aerosol direct forcing derived from satellite and ground-based observations. J Geophys Res 110(D24207). doi: 10.1029/2005JD006356

Chung SH, Seinfeld JH (2005) Climate response of direct radiative forcing of anthropogenic black carbon. J Geophys Res 110(D11):D11102. doi:10.1029/2004JD005441

Collins WD et al (2004) Description of the NCAR Community Atmosphere Model (CAM 3.0). Tech. Rep. NCAR/TN464+STR, National Center for Atmospheric Research, Boulder, $\mathrm{CO}, 226 \mathrm{pp}$

Cox PM et al (2008) Increasing risk of Amazonian drought due to decreasing aerosol pollution. Nature 453. doi:10.1038/nature 06960

Evan AT, Vimont DJ, Heidinger AK, Kossin JP, Bennartz R (2009) The role of aerosols in the evolution of tropical North Atlantic Ocean temperature anomalies. Science 324:778-781

Feldstein SB (2002) The recent trend and variance increase of the annular mode. J Clim 15:88-94

Forster P et al (2007) Changes in atmospheric constituents and in radiative forcing. In: Climate change 2007: the physical science basis. Contribution of working group I to the fourth assessment report of the intergovernmental panel on climate change. Cambridge University Press, Cambridge

Frierson DMW, Lu J, Chen G (2007) Width of the Hadley cell in simple and comprehensive general circulation models. Geophys Res Lett 34:L18804. doi:10.1029/2007GL031115

Fu Q, Johanson CM, Wallace JM, Reichler T (2006) Enhanced midlatitude tropospheric warming in satellite measurements. Science 312:1179

Gillett NP (2005) Northern Hemisphere circulation. Nature 437:496-496

Gillett NP, Allen MR, McDonald RE, Senior CA, Shindell DT, Schmidt GA (2002) How linear is the Arctic Oscillation response to greenhouse gases? J Geophys Res 107:D3. doi:10.1029/2001 JD000589
Haigh JD, Blackburn M, Day R (2005) The response of tropospheric circulation to perturbations in lower-stratospheric temperature. J Clim 18:3672-3685

Haynes PH, Marks CJ, McIntyre ME, Shepherd TG, Shine KP (1991) On the "downward control" of extratropical diabatic circulations by eddy-induced mean zonal forces. J Atmos Sci 48:651-678

Held IM (2000) The general circulation of the atmosphere, paper presented at 2000 Woods Hole Oceanographic Institute Geophysical Fluid Dynamics Program, Woods Hole Oceanographic Institute, Woods Hole, MA. http://www.whoi.edu/page.do? pid $=13076$

Holton JR (1992) An introduction to dynamic meteorology. Academic Press, New York, 511 pp

$\mathrm{Hu}$ Y, Fu Q (2007) Observed poleward expansion of the Hadley circulation since 1979. Atmos Chem Phys. 7:5229-5236

Ito A, Penner JE (2005) Historical emissions of carbonaceous aerosols from biomass and fossil fuel burning for the period 1870-2000. Global Biogeochem Cycles 19(GB2028). doi:10.1029/2004 GB002374

Johanson CM, Fu Q (2009) Hadley cell widening: model simulations versus observations. J Clim 22:713-2725

Kim MK, Lau WKM, Chin M, Kim KM, Sud YC, Walker GK (2006) Atmospheric teleconnection over Eurasia induced by aerosol radiative forcing during boreal spring. J Clim 19:4700-4718

Koch D et al (2009) Evaluation of black carbon estimations in global aerosol models. Atmos Chem Phys 9(22):9001-9026

Kushner PJ, Held IM, Delworth TL (2001) Southern Hemisphere atmospheric circulation response to global warming. J Clim 14:2238-2249

Levy RC et al (2003) Evaluation of the moderate-resolution imaging spectroradiometer (MODIS) retrievals of dust aerosol over the ocean during PRIDE. J Geophys Res 108(D19). doi: 10.1029/2002JD002460

Lorenz DJ, DeWeaver ET (2007) Tropopause height and zonal wind response to global warming in the IPCC scenario integrations. J Geophys Res 112. doi:10.1029/2006JD008087

Lu J, Deser C, Reichler T (2009) Cause of the widening of the tropical belt since 1958. Geophys Res Lett 36:L03803. doi: 10.1029/2008GL036076

Lu J, Vecchi GA, Reichler T (2007) Expansion of the Hadley cell under global warming. Geophys Res Lett 34:L06805. doi: 10.1029/2006GL028443

Mantsis DF, Clement AC (2009) Simulated variability in the mean atmospheric meridional circulation over the 20th century. Geophys Res Lett 36:L06704. doi:10.1029/2008GL036741

Meehl GA, Arblaster JM, Collins WD (2008) Effects of black carbon aerosols on the Indian monsoon. J Clim 21:2869-2882

Menon S, Hansen J, Nazarenko L, Luo Y, (2002) Climate effects of black carbon aerosols in China and India. Science 297:2250-2253

Miller RL, Schmidt GA, Shindell DT (2006) Forced annular variations in the 20th century Intergovernmental Panel on Climate Change Fourth Assessment Report models. J Geophys Res 111:D18101. doi:10.1029/2005JD006323

Mitchell JFB, Johns TC, Gregory JM, Tett SFB (1995) Climate response to increasing levels of greenhouse gases and sulphate aerosols. Nature 370:501-504

Novakov T, Ramanathan V, Hansen JE, Kirchstetter TW, Sato M, Sinton JE, Sathaye JA (2003) Large historical changes of fossilfuel black carbon aerosols. Geophys Res Lett 30(6). doi: 10.1029/2002GL016345

Osborn TJ (2004) Simulating the winter North Atlantic Oscillation: the roles of internal variability and greenhouse gas forcing. Clim Dyn 22:605-623

Podgorny IA, Conant WC, Ramanathan V, Satheesh SK (2000) Aerosol modulation of atmospheric and solar heating over the tropical Indian Ocean. Tellus B 52:947-958 
Raisanen J (2003) $\mathrm{CO}_{2}$-induced changes in the atmospheric angular momentum in CMIP2 experiments. J Clim 16:132-143

Ramanathan V, Carmichael G (2008) Global and regional climate changes due to black carbon. Nat Geosci 1:221-227

Ramanathan V, Crutzen PJ, Kiehl JT, Rosenfeld D (2001a) Aerosols, climate and the hydrological cycle. Science 294:2119-2124

Ramanathan V, Crutzen PJ, Lelieveld J, Mitra AP et al. (2001b) Indian Ocean Experiment: an integrated analysis of the climate forcing and effects of the great Indo-Asian haze. J Geophys Res 106(D22):28371-28398

Ramanathan V, Ramana MV, Roberts G, Kim D, Corrigan C, Chung C, Winker D (2007) Warming trends in Asia amplified by brown cloud solar absorption. Nature 448:575-578

Ramanathan V et al (2005) Atmospheric brown clouds: impacts on South Asian climate and hydrological cycle. Proc Natl Acad Sci 102:5326-5333

Randles CA, Ramaswamy V (2008) Absorbing aerosols over Asia: a geophysical fluid dynamics laboratory general circulation model sensitivity study of model response to aerosol optical depth and aerosol absorption. J Geophys Res 113:D21203. doi: 10.1029/2008JD010140

Rauthe M, Hense A, Paeth H (2004) A model intercomparison study of climate change signals in extratropical circulation. Int $\mathrm{J}$ Climatol 24:643-662

Reichler T, Dameris M, Sausen R (2003) Determining the tropopause height from gridded data. Geophys Res Lett 30(20):2042. doi: 10.1029/2003GL018240

Rind D, Perlwitz J, Lonergan P (2005) AO/NAO response to climate change: 1. Respective influences of stratospheric and tropospheric climate changes. J Geophys Res 110(D12107). doi: 10.1029/2004JD005103

Roberts DL, Jones A (2004) Climate sensitivity to black carbon aerosol from fossil fuel combustion. J Geophys Res 109:D16202. doi:10.1029/2004JD004676

Robock A (2000) Volcanic eruptions and climate. Rev Geophys 38:191-219

Roeckner EL, Bengtsson L, Feichter J, Lelieveld J, Rodhe H (1999) Transient climate change simulations with a coupled atmosphere-ocean GCM including the tropospheric sulfur cycle. J Clim 12:3004-3031

Rotstayn LD, Lohmann U (2002) Tropical rainfall trends and the indirect aerosol effect. J Clim 15:2103-2116

Rotstayn LD, Ryan BF, Penner JE (2000) Precipitation changes in a GCM resulting from the indirect effects of anthropogenic aerosols. Geophys Res Lett 27(19):3045-3048

Sato $M$ et al (2003) Global atmospheric black carbon inferred from AERONET. Proc Natl Acad Sci 100(11):6319-6324

Scaife AJ, Knight JR, Vallis GK, Folland CK (2005) A stratospheric influence on the winter NAO and North Atlantic surface climate. Geophys Res Lett 32:L18715. doi:10.1029/2005GL023226

Seidel DJ, Fu Q, Randel WJ, Reichler TJ (2008) Widening of the tropical belt in a changing climate. Nat Geosci 1. doi: 10.1038/ngeo.2007.38

Shindell DT, Faluvegi G (2009) Climate response to regional radiative forcing during the twentieth century. Nat Geosci. 2. doi:10.1038/NGEO473
Shindell DT, Schmidt GA, Mann ME, Faluvegi G (2004) Dynamic winter climate response to large tropical volcanic eruptions since 1600. J Geophys Res 109:D05104. doi:10.1029/2003JD004151

Shindell DT, Schmidt GA, Miller RL, Rind D (2001) Northern Hemisphere winter climate response to greenhouse gas, ozone, solar, and volcanic forcing. J Geophys Res 106(D7):7193-7210

Smith S, Andres R, Conception E, Lurz J (2004) Historical sulfur dioxide emissions 1850-2000: methods and results. Tech. Rep. PNNL-14537, Joint Global Change Research Institute

Song Y, Robinson WA (2004) Dynamical mechanisms for stratospheric influences on the troposphere. J Atmos Sci 61:1711-1725

Stenchikov G, Robock A, Ramaswamy V, Schwarzkopf MD, Hamilton K, Ramachandran S (2002) Arctic Oscillation response to the 1991 Mount Pinatubo eruption: effects of volcanic aerosols and ozone depletion. J Geophys Res 107(D24):4803. doi:10.1029/2002JD002090

Streets DG et al (2009) Anthropogenic and natural contributions to regional trends in aerosol optical depth, 1980-2006. J Geophys Res 114(D00D18). doi:10.1029/2008JD011624

Thompson DWJ, Wallace JM (2000) Annular modes in the extratropical circulation. Part I: Month to month variability. J Clim 13:1000-1016

Twomey S (1977) The influence of pollution on the shortwave albedo of clouds. J Atmos Sci 34:1149-1152

van Aardenne JA, Dentener FJ, Olivier JGJ, Klein Goldewijk CGM, Lelieveld J (2001) A 1 x 1 degree resolution dataset of historical anthropogenic trace gas emissions for the period 1890-1990. Global Biogeochem Cycles 15(4):909-928

Wang C (2004) A modeling study on the climate impacts of black carbon aerosols. J Geophys Res 109:D03106. doi: 10.1029/2003JD004084

Wang C (2007) Impact of direct radiative forcing of black carbon aerosols on tropical convective precipitation. Geophys Res Lett 34:L05709. doi:10.1029/2006GL028416

Williams GP (2006) Circulation sensitivity to tropopause height. J Atmos Sci 63:1954-1961

Williams KD, Jones A, Roberts DL, Senior CA, Woodage MJ (2001) The response of the climate system to the indirect effects of anthropogenic sulfate aerosol. Clim Dyn 17:845-856

Yin JH (2005) A consistent poleward shift of the strom tracks in simulations of 21 st century climate. Geophys Res Lett 32:L18701. doi:10.1029/2005GL023684

Yoshimori M, Broccoli AJ (2008) Equilibrium response of an atmosphere-mixed layer ocean model to different radiative forcing agents: global and zonal mean response. J Clim 21:4399-4423

$\mathrm{Yu} \mathrm{H}$ et al (2006) A review of measurement-based assessments of the aerosol direct radiative effect and forcing. Atmos Chem Phys 6:613-666

Zhang R, Delworth TL (2005) Simulated tropical response to a substantial weakening of the Atlantic thermohaline circulation. J Clim 18:1853-1860 